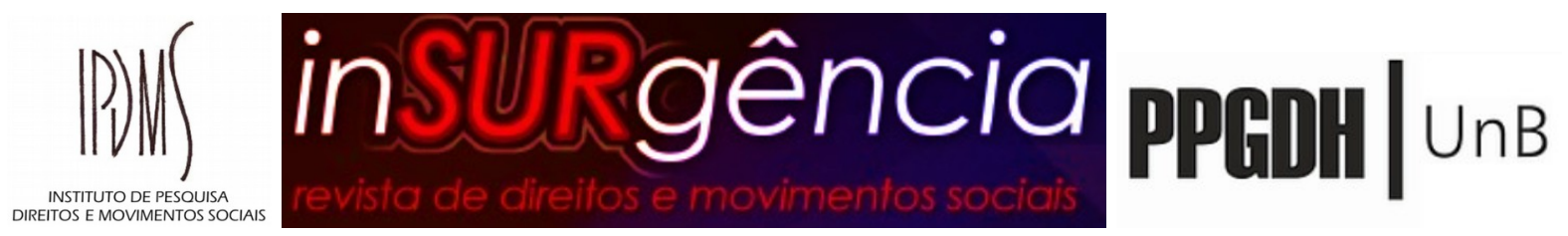

\title{
Ocupações urbanas em Minas Gerais: uma análise da política fundiária a partir da luta pelo direito à cidade
}

Urban occupations in Minas Gerais: an analysis of land policy from the struggle for the right to the city

Luiz Fernando Vasconcelos de Freitas ${ }^{1}$

Thayan Rodrigues Coutinho Neves ${ }^{2}$

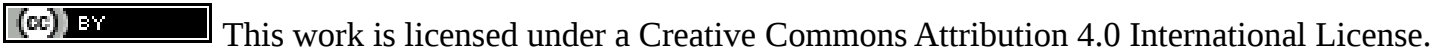

Resumo: Os movimentos de reforma urbana foram determinantes na consolidação do Capítulo constitucional da Política Urbana, do Estatuto da Cidade e da legislação nacional sobre regularização fundiária. Nos últimos anos tais políticas têm sido alvo de profundos retrocessos, expressos especialmente pela Medida Provisória 759, convertida na Lei 13.465/17. O artigo objetiva analisar o contexto e o projeto político que ensejaram a referida Lei e os limites e as possibilidades de disputas na sua interpretação e aplicação, a partir da conjugação das lutas políticas e jurídicas. Além da reflexão teórica, analisa-se casos concretos de ocupações urbanas e suas relações com os conflitos fundiários e as normas de regularização fundiária, no sentido de disputa pela concretização do direito à cidade.

Palavras Chave: Conflitos Fundiários. Regularização Fundiária. Ocupações Urbanas. Moradia. Direito à Cidade.

Abstract: The urban reform movements were determining in consolidating the Constitutional Chapter of Urban Policy, the City Statute and national legislation on land regularization. In recent years, such policies have been the target of deep setbacks, expressed especially by

1 Mestre e Doutorando em Direito pela Universidade Federal de Minas Gerais. Advogado popular e militante das Brigadas Populares com atuação em conflitos fundiários no Estado de Minas Gerais. Email: luizfernandovf28@gmail.com. ORCID: https://orcid.org/0000-0001-9968-6767.

2 Bacharel e mestre em Direito pela Universidade Federal de Minas Gerais. Advogado popular e militante das Brigadas Populares com atuação em conflitos fundiários no Estado de Minas Gerais. Email: thayanrodrigues@gmail.com. ORCID: 


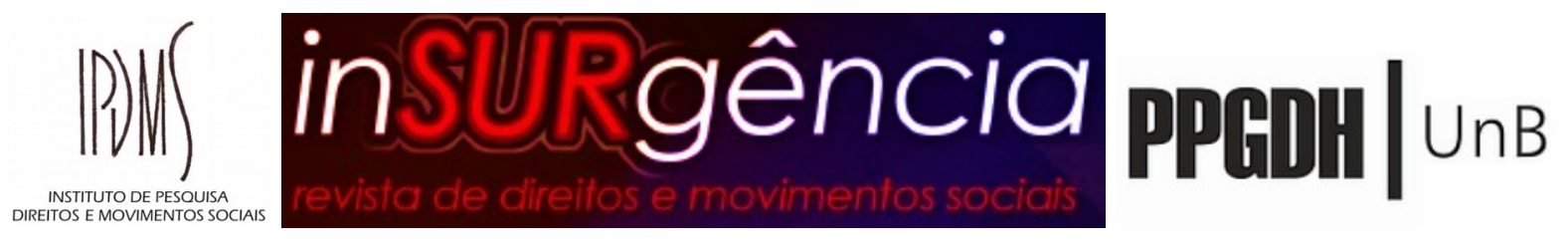

Provisional Measure 759, converted into Law 13.465/17. The article aims to analyze the political context and project that gave rise to that Law and the limits and possibilities of disputes in its interpretation and application, based on the combination of political and legal struggles. In addition to theoretical reflection, we analyze concrete cases of urban occupations and their relationship with land conflicts and the rules for land regularization, in the sense of disputing the realization of the right to the city.

Keywords: Land conflicts. Land regularization. Urban Occupations. Housing. Right to the City.

\section{1) INTRODUÇÃO}

O contexto de formação das cidades brasileiras, à semelhanças das cidades latino americanas, é marcado pelo aprofundamento das desigualdades sociais, com grandes reflexos na negação do acesso aos direitos básicos pelos pobres urbanos. As políticas fundiárias adotadas desde o período colonial até o presente se serviram para a concentração de terra nas mãos de poucos, negando ao povo o acesso à terra, à moradia e aos serviços básicos. Nesse cenário, a informalidade na ocupação do solo urbano é uma das alternativas das classes populares para acesso à terra e à moradia, na luta pelo reconhecimento de seus direitos, o que vem acompanhando de graves conflitos fundiários.

Ao longo de anos de luta, especialmente no processo de redemocratização recente, os movimentos de reforma urbana lograram consagrar na Constituição Federal de 1988 um capítulo inédito e específico sobre a política urbana. Nesse sentido se seguiram a aprovação do Estatuto de Cidade e outras legislações urbanísticas, inclusive a Lei de 11.977/09, que também dispunha sobre a regularização fundiária de assentamentos localizados em áreas urbanas.

Nos últimos anos, especialmente a partir do ano de 2016, o Brasil vivencia uma conjuntura de retrocessos profundos, o que também se expressa no campo da política urbana e fundiária. Expressão disso foi a edição da Medida Provisória 759, posteriormente convertida na Lei 13.465/17, que alterando diversas leis vigentes, alterou a regulamentação das terras da Amazônia Legal e das terras pertencentes à União, além das normas de regularização fundiária rural e urbana.

O presente artigo visa analisar o contexto e o projeto político que gestaram a Medida Provisória 759 e a Lei 13.465/17, bem como suas repercussões na política fundiária urbana 


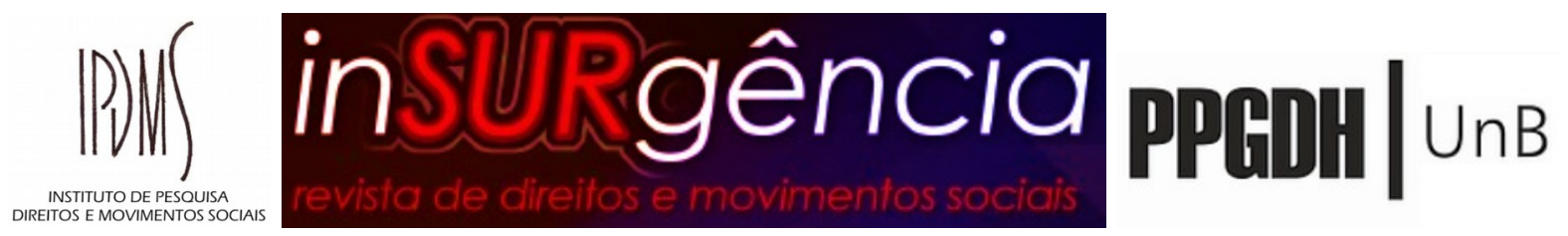

brasileira. Diante dessa análise busca-se trabalhar perspectivas que, partir da conjugação de estratégias de luta, possibilitem a disputa pela interpretação e aplicação da referida legislação em um sentido de concretização do direito à cidade. Além da reflexão teórica, apresenta-se casos concretos de conflitos fundiários envolvendo as ocupações urbanas Tomás Balduíno, Candeeiro, Vicentão e das ocupações de Timóteo, buscando visualizar possibilidades e limites de disputa pela interpretação e aplicação das normas de regularização fundiária, a partir das lutas políticas e jurídicas desenvolvidas no contexto de militância e advocacia popular.

\section{2) A MEDIDA PROVISÓRIA (MP) 759 E A LEI 13.465/2017: O PROJETO DE ATAQUE AO DIREITO À CIDADE}

No dia 23 de dezembro de 2016 foi publicada a Medida Provisória 759 para dispor sobre a regularização fundiária rural e urbana, a liquidação de créditos concedidos aos assentados da reforma agrária e sobre a regularização fundiária no âmbito da Amazônia Legal, além de instituir mecanismos para aprimorar a eficiência dos procedimentos de alienação de imóveis da União, dentre outras providências.

A norma está inserida no contexto do impeachment ocorrido no Brasil em 2016 momento em que a então Presidenta Dilma Rousseff foi deposta de forma ilegítima por um golpe já que o fundamento pelo qual a presidenta foi retirada do cargo de suprema mandatária da nação não constitui crime de responsabilidade como exige a Constituição Federal de 1988. Ela foi acusada de promover operações de crédito irregulares. Sobre isso convém ver o que diz os juristas Alexandre Gustavo Melo Franco de Moraes Bahia, Emílio Peluso Neder Meyer, Diogo Bacha e Silva, Marcelo Andrade Cattoni de Oliveira e Paulo Roberto Iotti Vecchiatti:

Ocorre que referidos fatos são atípicos, ou seja, não constituem crimes de responsabilidade. O crime em que tentam enquadrar as chamadas "pedaladas fiscais" (art. 10, 9, da Lei 1079/50) refere-se à conduta de realizar "operação de crédito" com outro ente federativo ou unidades da Administração Indireta destes. A uma, não há operação de crédito na conduta da Presidente da República - tanto que o TCU disse que se trata de conduta que, a seu ver, "se assemelha" a operações de crédito. "Se assemelhar" a algo é diferente de "ser” este algo. Trata-se de julgamento por analogia (por equivalência). Só que crimes de responsabilidade são crimes, conforme os precedentes que formaram a Súmula 722 do STF (ela diz que eles são de competência da União pelos precedentes que a geraram falarem que se trata de matéria penal) e é notório que não existe “crime por analogia”. (...) Logo, inexiste crime de responsabilidade aqui - e trata-se de uma questão de qualidade, não de quantidade, sendo irrelevante para saber se é ou não crime o suposto volume maior de valores da atual Presidente da República relativamente a seus antecessores (isso foi, aliás, recentemente afirmado também por Virgílio Afonso da Silva).(BAHIA et al, 2016) 


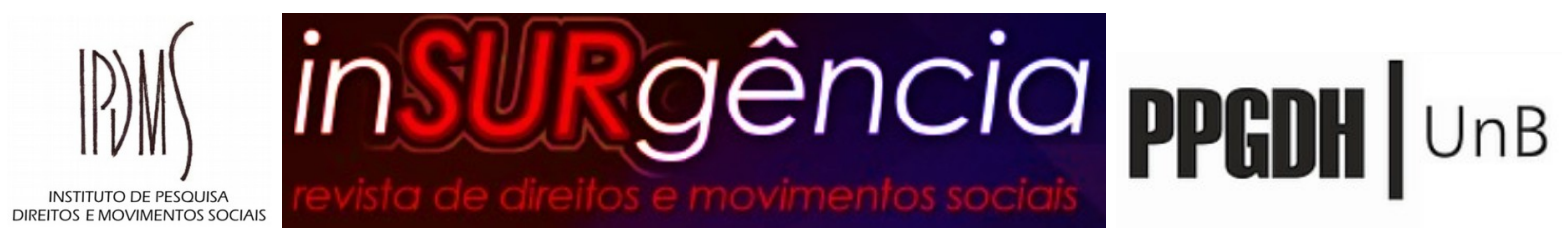

Assim, a Medida Provisória 759 tinha um objetivo nítido de orientar a questão fundiária no país por um viés conservador e privatista em contraponto ao princípio constitucional da função social da propriedade (Art. 5 $5^{\circ}$ XXIII e art. 170, II). A referida MP se transformou na Lei 13.465, em 11 de julho de 2017, com vícios de inconstitucionalidade como por exemplo a ausência de relevância e urgência necessários para a edição da espécie normativa em questão.

A Lei 13.465/17 insere-se no rol de medidas antidemocráticas que visam aprofundar no país o modelo neoliberal de apropriação privada dos territórios. Junto com outras medidas como as reformas da previdência e trabalhista, a limitação dos gastos públicos com um novo regime fiscal em vigor a partir da Emenda Constitucional 95 e a entrega de campos do pré-sal brasileiro, a norma emerge do sistema do Golpe de 2016 e se sustenta nos pilares intocáveis da propriedade privada, do sistema financeiro excludente e concentrador e da desconstitucionalização do pacto político de 1988 apontando o esgotamento do arranjo político da Nova República.

No que toca à questão urbana todo um processo de décadas de construção democrática da legislação jurídico-urbanística brasileira e de debate público foi desconsiderado violandose o princípio da gestão democrática das cidades ao se fazer por ato unilateral da presidência da república a Medida Provisória 759, transformada na Lei 13.465/17. Uma linha temporal que teve um marco importante no processo Constituinte de 1988 e que logrou aprovar o primeiro capítulo de Política Urbana da história constitucional brasileira (Arts. 182 e 183 da CF-88), passando depois pela promulgação do Estatuto das Cidades (Lei 10.257-2001), dentre outras legislações importantes.

A Medida Provisória 759, posteriormente Lei 13.465/17 revogou uma série de dispositivos legais tais como parte da_Lei 11.977/2009, do Minha Casa, Minha Vida, no que pertine às normas de regularização fundiária de assentamentos urbanos, e mitigou princípios expressos do Estatuto das Cidades (Lei 10.257/2001) que regem a política e o desenvolvimento urbano, além de paralisar procedimentos de regularização fundiária que já estavam em curso pela lei do Minha Casa, Minha Vida.

Na Lei 13.465/17 aparece a figura da Regularização Fundiária Urbana (Reurb) que prevê dentre os seus objetivos a ampliação do acesso à terra urbanizada pela população de baixa renda, a promoção da integração social e a geração de emprego e renda, a garantia do direito social à moradia digna e às condições de vida adequadas e o pleno desenvolvimento 


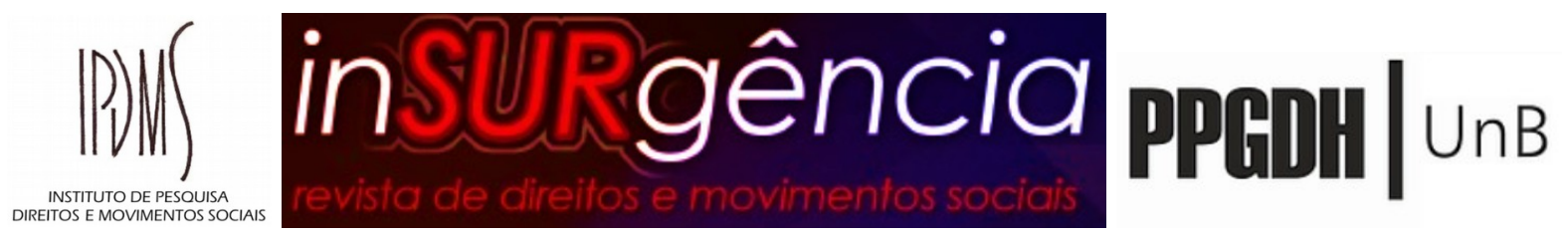

das funções sociais da cidade de forma a garantir o bem estar de seus habitantes. No entanto, já na exposição de motivos da MP 759 aparece o real objetivo de tal espécie normativa:

\begin{abstract}
É que o reconhecimento, pelo Poder Público, dos direitos reais titularizados por aqueles que informalmente ocupam imóveis urbanos, permite que estes imóveis sirvam de base para investimento do capital produtivo brasileiro, à medida que poderão ser oferecidos em garantia de operações financeiras, reduzindo custos de crédito, por exemplo.” (BRASIL, 2016)
\end{abstract}

O Senador Romero Jucá, relator da MP 759, em entrevista à TV Senado em 25/04/2017 afirmou que o objetivo da norma seria fortalecer a economia como se vê no seguinte trecho: “(...) No sentido de isso poder representar também um fortalecimento à microeconomia, porque na hora em que você tem uma terra regularizada essa terra pode ser dada em garantia para que haja produção” (BRASIL, 2017).

Ou seja, a titularidade da propriedade facilitaria o crédito, mas ao revés pode gerar o endividamento das famílias empobrecidas e o enriquecimento de atores do sistema financeiro pela movimentação do mercado de crédito com lastro em propriedade fundiária. Tal objetivo político nada mais é que a malfadada tentativa de aplicação no Brasil das ideias de Hernando de Soto, economista peruano, para quem o acesso à ordem fundiária formal, com consequente acesso ao crédito, pode fomentar o desenvolvimento econômico, combater a pobreza e aquecer a economia. Frisa-se que tal proposição empreende uma gestão financeira da regularização fundiária por via da atribuição de títulos de propriedade individual aos ocupantes que a partir daí se integrariam ao mercado financeiro formal e não a partir de uma lógica de regularização fundiária plena envolvendo as dimensões jurídica, urbanística, ambiental e social.

A estrutura fundiária brasileira desde a Lei de Terras de 1850 é focada na propriedade privada favorecendo grileiros e latifundiários e restringido o acesso à terra em um período pós-abolição da escravidão. Em igual sentido a Lei 13.465-17 não observa, de fato, as reais necessidades de quem tem o seu direito à moradia sonegado, mas preocupa-se com a engrenagem de reprodução financeira da terra. Assim sendo, consolida ainda mais a propriedade privada da terra reforçando uma injustiça histórica ao priorizar a sua modulação às necessidades especulativas do mercado financeiro.

A questão de fundo das disputas territoriais hoje no Brasil é que a concentração fundiária está atrelada à concentração do poder político. A propriedade funciona nesse cenário 


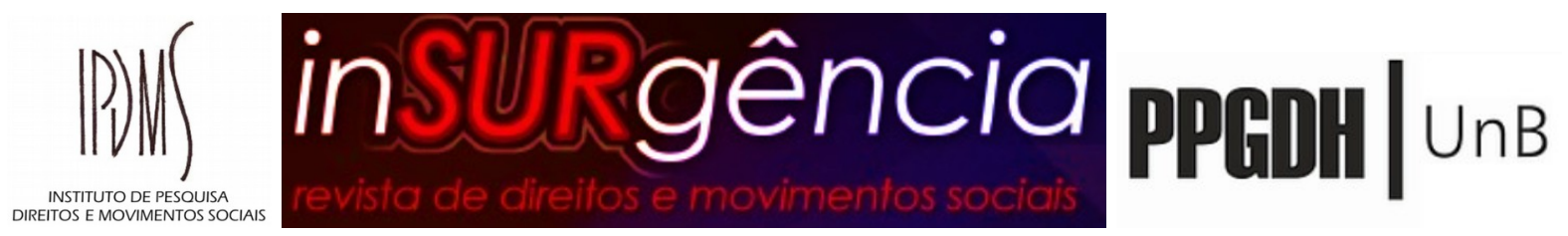

como relação social de dominação de uma elite política e econômica sobre as maiorias sociais.

Titular propriedades sem a garantia de concretização dos direitos fundamentais, notadamente os direitos à educação, saúde, lazer, trabalho, alimentação, transporte público e com o intuito apenas de fomentar o mercado de créditos é não efetivar o direito à cidade. Fazer uma regularização fundiária sem enfrentar a apropriação capitalista das cidades e sem recuperar as mais valias fundiárias geradas por investimentos públicos no espaço urbano é manter o sistema de aliança entre capital-Estado na reprodução das cidades.

\section{3) A NECESSIDADE DE UMA LEITURA EM PROL DO DIREITO À CIDADE}

$\mathrm{Na}$ perspectiva urbana brasileira, a informalidade apresenta diversas dimensões e constitui muito mais a regra do que a exceção, não sendo necessariamente um atributo de classe social restrito aos pobres, embora certamente os atinja de forma muito mais perversa em razão da lógica mercantilizada da cidade e da extrema desigualdade social que transforma direitos em mercadorias acessíveis apenas a poucos privilegiados (COSTA, 2006). Estima-se que $70 \%$ (setenta por cento) da produção residencial nas cidades brasileiras é autoconstruída e, no universos dos assentamentos informais ocupados predominantemente por população de baixa renda, são diversas as suas tipologias, como loteamentos periféricos, as vilas e favelas e as ocupações urbanas, com diferentes aspectos de segurança da posse e de acessos a serviços e equipamentos públicos (NASCIMENTO, 2016).

Em um contexto de capitalismo financeirizado, a terras são ativos altamente disputados e os moradores de territórios populares se encontram em um estado de insegurança permanente, ameaçados constantemente por despejos e remoções forçadas. Esse estado de coisas, tem forte relação com as políticas fundiárias e consequências ainda mais drásticas nos países de economia emergente, como na América Latina. A segurança ou insegurança da posse deve ser compreendida como uma questão de economia política, onde a legislação, as instituições e os processos de tomada de decisão referentes à moradia e ao acesso à terra são perpassados pelas estruturas de poder, que incidem para garantir ou negar as condições de uso aos moradores de baixa renda, em uma dinâmica que se respalda pela inclusão ou exclusão na cidade (ROLNIK, 2015).

O capitalismo produz e reproduz não apenas mercadorias, mas também relações sociais, de forma que o crescimento desordenado das cidades nada mais é que a própria realização da 


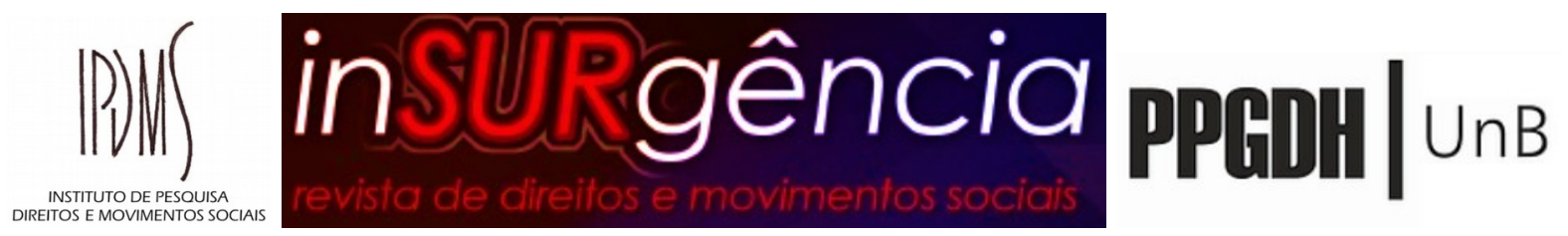

ordem de produção social e apropriação privada, determinada pela lógica do capital. A partir dessa constatação, pode-se entender que a busca por uma "nova ordem urbana” e as “cidades sustentáveis” não passam de uma ilusão (COUTINHO, 2011).

De fato, não será o refúgio no direito e a busca por uma justiça eterna que garantirão as transformações econômica e sociais necessárias para a promoção do bem comum de todos e o desaparecimento da sociedade de classes (ENGELS, 2015). Contudo, dadas as condições de espoliação e a sustentação instrumental e discursiva que o direito lhes fornece, às lutas sociais concretas também devem se somar as disputas nos diversos campos, inclusive o jurídico. Através de tais formas de lutas e disputas, é importante evidenciar que as contradições se apresentam não apenas no seio da sociedade, entre suas classes, mas também entre esse modelo de sociedade e a ordem jurídica por ela mesma instituída.

É necessário que, com as devidas cautelas, se conjugue as lutas via ações diretas, entendidas como o conjunto de práticas de luta conduzidas apesar do Estado ou contra o Estado, ou seja, sem vínculo institucional ou econômico imediato com canais e instâncias estatais, e a luta institucional, entendida como o uso de canais, instâncias e recursos estatais (SOUZA, 2012). Isso porque, numa sociedade conflituosa e contraditória, o Estado, conjunturalmente, pode apresentar oscilações, vulnerabilidades e potencialidades, a serem eventualmente exploradas pelos movimentos sociais, onde também se situam o instrumental e o discurso jurídicos. É fundamental que, numa sociedade como a brasileira e diante de suas exigências econômicas, sociais, culturais, jurídicas e políticas, se avance nas transformações estruturais fundamentais, como a reforma urbana, entendida como uma tarefa de "revolução dentro da ordem” a ser empreendida desde os despossuídos e com consequências socializadoras de importância estratégica (FERNANDES, 2000).

Não se deve ignorar que o avanço obtido com a consagração, pela primeira vez na história brasileira, de um capítulo próprio dedicado à política urbana na Constituição Federal de 1988 é fruto da articulação de amplas lutas sociais pela reforma urbana. Tais lutas, a partir de uma ressignificação das relações com o campo jurídico-institucional, possibilitaram a politização do debate e a construção de plataformas jurídico-políticas pautadas na função social da propriedade e da cidade, na concepção de novos direitos urbanos, na cidadania e na justiça social quanto ao uso e usufruto do espaço urbano, no sentido de uma vida digna (SILVA, 1991). 


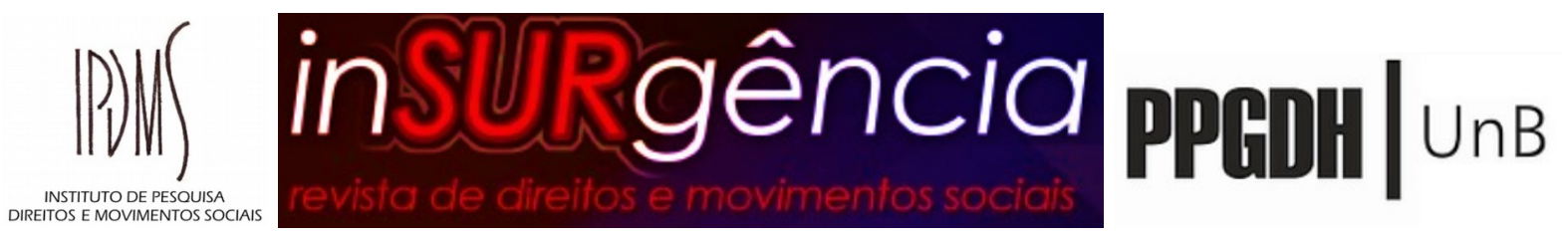

Também a aprovação da Lei 10.257/01, que instituiu o Estatuto da Cidade, é fruto do acúmulo dessas forças progressistas, embora também imbuída das aspirações conservadoras fortemente influenciadas pelo mercado imobiliário. ${ }^{3} E$ inegável o avanço legislativo havido com a aprovação do Estatuto da Cidade, mas o esvaziamento de sua efetividade deixa evidente que é necessário não fetichizar a lei, mas, a partir dela e para além dela, apostar na luta e na ação política como elementos fundamentais na busca pelo acesso à terra urbana e à moradia num sentido mais amplo de reforma urbana (GAIO, 2015).

No Brasil, há uma relação entre a reforma urbana, entendida como plataforma de lutas por um marco regulatório urbanístico fundamental para a democratização do solo urbano, especialmente quanto à moradia social, o cumprimento da função social da propriedade e da cidade e a gestão democrática da cidade, além de outros direitos urbanos, e o Direito à Cidade, que cumpre uma função de organização das lutas em torno de um denominador comum (GAIO, 2016).

O Direito à Cidade, em sua gênese com Henri Lefebvre, no contexto da França de 1968, tem uma faceta teórico conceitual associada à outra de cunho prático-reivindicativo. No Brasil foi recepcionado no contexto da ditadura militar, com repercussões em diferentes campos do conhecimento na relação entre setores acadêmicos e movimentos sociais urbanos. Sob essa baliza da práxis, de forma a conjugar as dimensões da teoria e da prática urbana, o Direito à Cidade envolve a reflexão sobre como a cidade é produzida de maneira desigual e, assim, como agir sobre a cidade. Assume, então, diversas significações que vão desde o seu entendimento como a luta por direitos e acesso equitativo a serviços e equipamentos coletivos, passando pela busca por cidadania no sentido de participar de forma democrática da gestão urbana, até a concepção de transformação do cotidiano e da vida urbana, em uma perspectiva de democracia radical que permita o enfrentamento das relações de poder vigentes (TAVOLARI, 2016). ${ }^{4}$ A plurissignificação do termo possibilita a aglutinação de pautas e movimentos, bem como o coloca como bandeira não estática, mas sim passível de abarcar o

3 Como exemplos pode-se referir à da necessidade de previsão nos Planos Diretores e regulamentação em leis específicas para aplicação dos instrumentos da política urbana, esvaziando a aplicação imediata e a vinculatividade das previsões do Estatuto; as disposições sobre as operações urbanas consorciadas, importante instrumento de atendimento das demandas dos capitais imobiliários e construtivos via flexibilização das normas urbanísticas; e as disposições sobre coeficiente de aproveitamento diferenciado para áreas específicas dentro da zona urbana, esvaziando a outorga onerosa do direito de construir como instrumento de recuperação de mais valias e justa distribuição dos benefícios e ônus decorrentes do processo de urbanização.

4 Para uma análise do percurso e das perspectivas sobre o conceito de direito à cidade, ver TAVOLARI, Bianca. Direito à cidade: uma trajetória conceitual. Novos Estudos Cebrap, nº 104, p. 93-109, mar. 2016. 


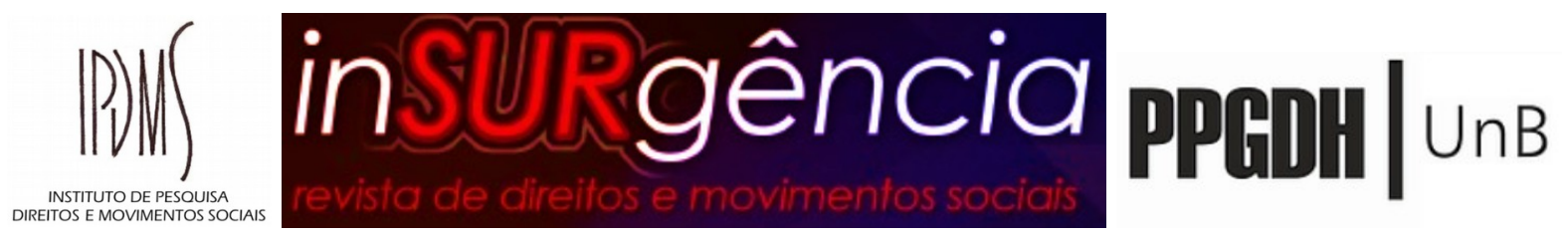

dinamismo das reivindicações e formas de lutas sociais, conforme a conjuntura em que se inserem.

Contudo, é necessário não enclausurar a potência do Direito à Cidade nos estreitos limites da institucionalidade, bem como evitar a sua apropriação pelo aparato Estatal e pelas elites urbanas, mantendo-o aberto não apenas para a incorporação de novos direitos, mas principalmente às insurgências contra a lógica do capital e do Estado. Assim, entende-se adequado, para os avanços no campo jurídico, pautar-se pela busca de efetividade dos instrumentos da ordem jurídico-urbanística (GAIO, 2016). Isso porque o direito urbanístico, como campo essencialmente interdisciplinar, especialmente com o urbanismo, se estrutura em princípios que devem ser compreendidos na dimensão da sociedade contemporânea. A interpretação das relações que se constroem na cidade deve ter como premissa o vínculo entre a forma jurídica e a forma urbana, à luz da realidade concreta e das práticas sociais instituintes de direitos difusos e redefinidoras do sentido das normas jurídicas (CAVALLAZZI, 2011).

No âmbito dos conflitos fundiários urbanos, a perspectiva dominante se pauta pela culpabilização dos moradores de assentamentos informais, desconsiderando o processo de segregação urbana que leva a essas situações e desqualificando as pessoas e comunidades de forma a concluir pela não aplicação dos direitos humanos a elas. Contudo, já existe uma forte construção jurídica em torno dos direitos humanos que promove a proteção da moradia adequada e condena a prática das remoções forçadas, exigindo a problematização da questão a partir de uma visão crítica e complexa desses direitos. Em uma perspectiva crítica, é fundamental que, com respaldo na construção jurídica e para além dela, se compreenda que o reconhecimento de direitos se dá em contextos e processos de lutas e relações sociais concretas desenvolvidas em movimentos históricos normativos, institucionais e sociais que possibilitam a transformação de comportamentos políticos. Nesse sentido que também se constroem resistências na luta pela garantia do direito ao acesso à terra e à moradia e à participação das pessoas nas decisões que as afetem, como garantia do direito à cidade (MULLER, 2014).

\section{4) A SEGURANÇA DA POSSE: ENTRE OS CONFLITOS FUNDIÁRIOS E OS INSTRUMENTOS DE REGULARIZAÇÃO FUNDIÁRIA}

Na lógica de produção e reprodução mercantilizada da cidade, a população de baixa renda, sem condições de pagar pelos preços exigidos pelo mercado e diante da ausência de 


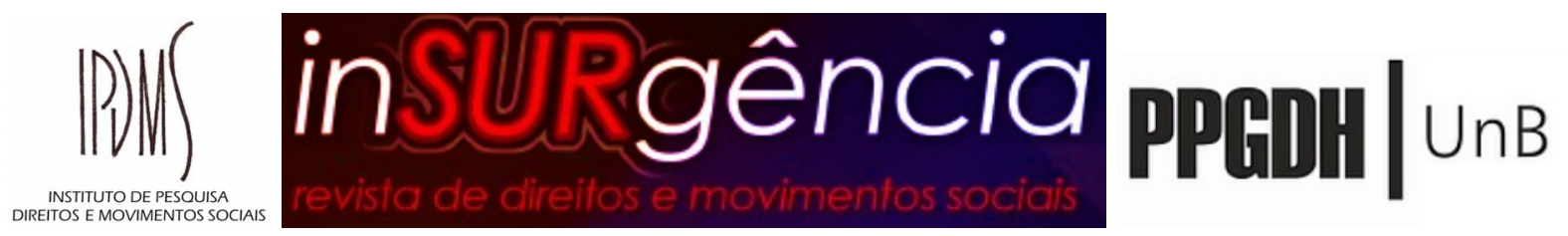

políticas públicas efetivas, tem garantido historicamente seu direito à moradia pela ocupação de imóveis desocupados. De forma espontânea ou organizada, a partir da gestão comunitária, as comunidades populares tem auto construído sua moradia e a própria cidade.

Contudo, diante das disputas pela terra e as constantes ameaças de despejos e remoções forçadas, ${ }^{5}$ a organização política para a luta tem sido o principal instrumento de resistência dessas comunidades pela permanência e consolidação de seus territórios. Por meio de formas e instrumentos diversos, via ação direta e institucional, as lutas populares têm pautado o reconhecimento de seus direitos, em regra negados pelos Poderes Públicos.

A negativa do reconhecimento de direitos das comunidades evidencia um estado de coisas violatório de diversos direitos reconhecidos nacional e internacionalmente. ${ }^{6}$ Deve-se garantir por todos os meios apropriados que, independentemente do tipo de posse, todas gozem de um grau de segurança que garanta proteção contra remoções forçadas. É, portanto, uma violação de direitos humanos a remoção permanente ou temporária contra a vontade dos indivíduos, famílias ou comunidades das casas ou terras que ocupam, sem a provisão e o acesso a formas adequadas de garantia de seu direito à moradia. Trata-se de direitos que ensejam responsabilidades do Estado, por todos os seus Poderes e Entes.

A resolução dos conflitos fundiários e garantia do direito à moradia nesses contextos exige a compreensão de que nos conflitos que envolvem a propriedade e a posse, a solução deve se dar pela avaliação concreta do cumprimento da função social de ambos os direitos (TORRES, 2010). Essa avaliação deve pautar tanto a posição do Poder Judiciário no julgamento de casos concretos quanto dos Poderes Legislativo e Executivo na formulação e execução de políticas públicas e na incidência em casos que exijam sua intervenção.

É fundamental, ainda, que se avancem em políticas efetivas de mediação e resolução de conflitos fundiários com a perspectiva de garantia do direito à moradia. ${ }^{7}$ Contudo, mesmo

5 Pode se compreender por conflitos fundiários coletivo os casos de conflitos coletivos pelo uso, posse ou propriedade de imóvel, urbano ou rural, envolvendo grupos que demandam proteção especial do Estado, tais como trabalhadores e trabalhadoras rurais sem terra e sem teto, povos indígenas, comunidades quilombolas, povos e comunidades tradicionais, pessoas em situação de rua e atingidos e deslocados por empreendimentos, obras de infraestrutura ou congêneres, conforme a Resolução $\mathrm{n}^{0}$ 10, de 17 de outubro de 2018, do Conselho Nacional de Direitos Humanos, que dispõe sobre soluções garantidoras de direitos humanos e medidas preventivas em situações de conflitos fundiários coletivos rurais e urbanos.

6 A título das normas reconhecedoras de direitos, destaca-se o art. $6^{\circ}$ da CF/88, o Pacto Internacional Sobre Direitos Econômicos, Sociais e Culturais e seus respectivos Comentários Gerais $\mathrm{n}^{\circ} 4$ e 7, o Estatuto da Cidade e demais normas referidas ao longo deste artigo.

7 Sobre a mediação de conflitos diversas normas foram editadas e instâncias foram constituídas, mas ainda carentes de real efetividade na solução garantidora dos direitos das comunidades. A título de exemplo, cita-se Resolução n 10/2018 do Conselho Nacional de Direitos Humanos, bem como, no Estado de Minas Gerais os Centros Judiciários de Solução de Conflitos e Cidadania (CEJUSC) e a Mesa Estadual de Diálogo e Negociação Permanente com Ocupações Urbanas e Rurais (Mesa de Diálogo). 


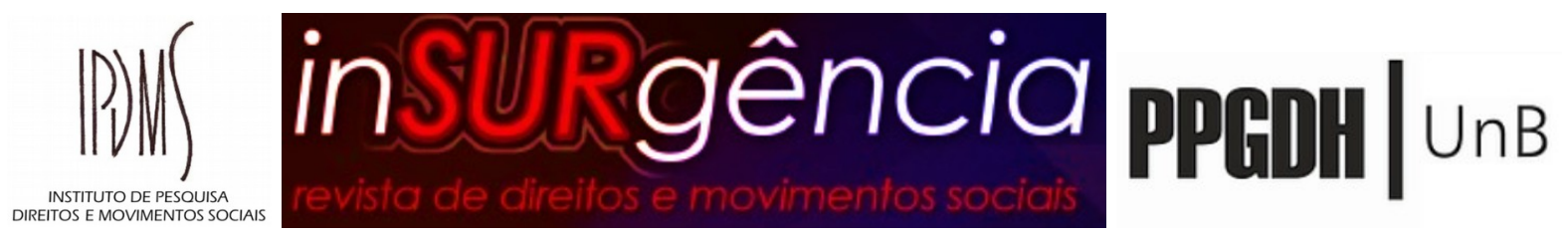

com vários instrumentos disponíveis o que tem ocorrido é a instrumentalização política dos discursos jurídicos e urbanísticos para a negativa de direitos, desconsiderando até mesmo a existência de direitos fundiários já adquiridos pelas comunidades, obstaculizando os avanços fundamentais para a resolução de conflitos e a promoção da regularização fundiária FERNANDES e PEREIRA, 2010).

Diante desse cenário, e considerando que é a partir dos processos concretos de lutas que se visualizam as possibilidade e os limites da disputa institucional para a transformação de interpretações jurídicas e de comportamentos políticos, cabe analisar como casos concretos de conflitos fundiários tem apresentado perspectivas de interpretação e aplicação de instrumentos de regularização fundiária.

\section{1) A OCUPAÇÃO TOMÁS BALDUÍNO E A REURB-S}

A Ocupação Tomás Balduíno, localizada no Município de Ribeirão das Neves/MG, se constituiu em uma parcela de área com características rurais de antigas fazendas, até então em terra nu, sem qualquer utilização e completamente abandonada. A área é de suposta propriedade de herdeiros que jamais concederam qualquer função socialmente útil ao terreno, retendo a terra para fins meramente especulativos em zonas de expansão urbana e de uso preferencialmente residencial.

Atualmente, na comunidade, que se iniciou no ano de 2013, moram mais de trezentas famílias, com casas em alvenaria e boa qualidade construtiva, com ruas largas que atendem aos parâmetros urbanísticos adequados e se integram às vias já existentes com integração ao bairro no que diz respeito à utilização dos serviços e equipamentos básicos pelos moradores. Além dos comércios locais, pelas características rururbanas do assentamento, há diversos quintais produtivos e hortas, coletivas e individuais, com uma grande diversidade de frutas, hortaliças, plantas medicinais e criação de animais de pequeno porte, que servem de fonte de sustento e geração de renda aos moradores. Parte da produção agroecológica é comercializada pela venda direta entre agricultores urbanos da comunidade e os coprodutores que consomem os produtos, num processo de corresponsabilização pela constituição de Comunidade que Sustenta a Agroecologia (CSA), além das feiras nas quais participam os agricultores. Ademais, verifica-se o desenvolvimento pelos moradores, com assessoria técnica, de sistema de coleta de resíduos da comunidade, sistemas de drenagem e infiltração de águas pluviais e de sistemas de tratamento de água. 


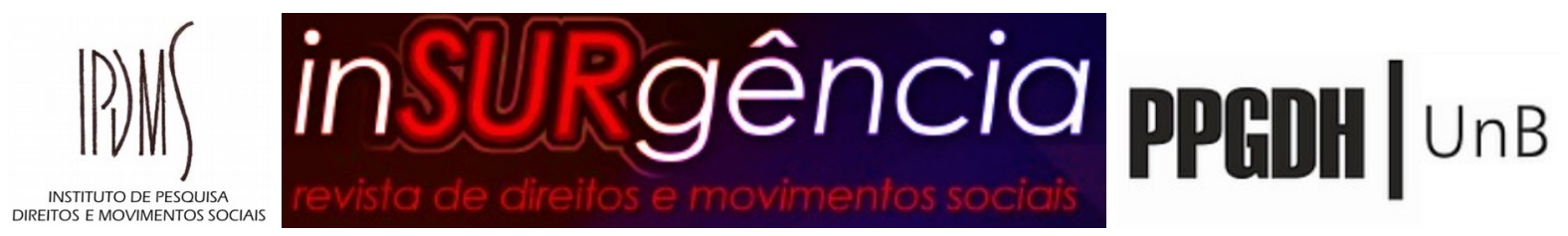

A comunidade resiste às diversas ordens de despejo desde o ano de 2014, num processo de reintegração de posse movido pelos supostos herdeiros da área (TJMG nº 051252353.2015.813.0024 e $\mathrm{n}^{0}$ 0512531-30.2015.813.0024). Para além do confronto fundamental entre a posse a propriedade sobre o imóvel, que deveria se resolver concretamente pela prevalência da função social, outros elementos devem ser levados em consideração. Em anos resistência, várias são as formas de luta pela permanência e consolidação da comunidade, contra o Estado e a propriedade privada especulativa, pelo Estado quando a luta contra possibilitou alternativas políticas ou jurídicas para avançar, e para além do Estado, no desenvolvimento da organização comunitária e política.

No âmbito do conflito fundiário, como conquista das lutas, além de diversos outros apoiadores da ocupação, o Legislativo e o Executivo municipais se comprometeram com a resolução do conflito e a regularização fundiária da comunidade. ${ }^{8}$ Por intermédio da Defensoria Pública foi requerida a instauração de procedimento de Regularização Fundiária Urbana de Interesse Social (Reurb-S). A Prefeitura de Ribeirão das Neves, então, instaurou o procedimento administrativo para Rurb-S da Ocupação Tomás Balduíno, classificada com núcleo informal consolidado ocupado predominantemente por população de baixa renda. ${ }^{9}$

Diante de tal fato novo, os advogados populares que representam judicialmente a comunidade, a Defensoria Pública, o Ministério Público e a própria Procuradoria Geral do Município se manifestaram nos autos requerendo a revogação da ordem de reintegração de posse. Os diversos argumentos apresentados, em síntese, dizem da incompatibilidade do cumprimento da ordem de reintegração de posse com a instauração da Reurb-S, fato novo de grande relevância jurídica que evidencia o reconhecimento da ocupação pelo Município, no âmbito de sua competência constitucional e legal, havendo diversos instrumentos a serem aplicados para a resolução justa e pacífica do conflito com a regularização da comunidade. Nesse sentido, ficam evidentes os interesses públicos e sociais que se sobrepõem ao interesse privado, devendo ser revogada a ordem de reintegração de posse e ser garantidos os direitos fundamentais dos moradores.

8 Os compromissos foram firmados em atas ao longo de diversas tratativas junto à Mesa Estadual de Diálogo e Negociação Permanente com Ocupações Urbanas e Rurais. Ademais, a Prefeitura apresentou um conjunto de estudos e ofícios sobre alternativas de resolução do conflito e regularização fundiária da comunidade e a Câmara Municipal aprovou uma moção de apoio unânime empreender todos os atos necessários, inclusive legislativos, para a garantia desse compromisso (moção 043/2019).

9 Foi editada a Portaria/Gab n. ${ }^{\circ}$ 056/2018, assinada pelo Prefeito, o Secretário Municipal de Planejamento e Urbanismo e o Procurador Geral do Município, em conformidade com o art. 13, I, da Lei 13.465/17. 


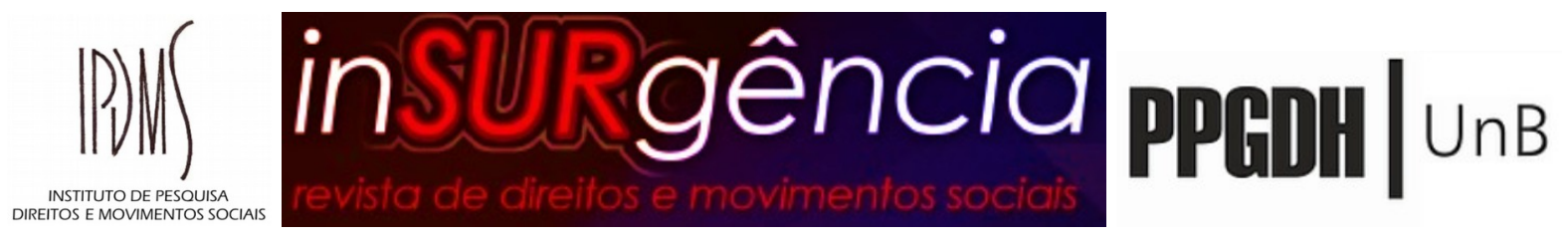

Contudo, o Juiz da Vara Agrária ${ }^{10}$, desconsiderando por completo todos os elementos levados ao processo e se apoiando tão somente na discordância isolada e não fundamentada dos supostos proprietários, simplesmente determinou o cumprimento da ordem de despejo. A questão foi levada em recurso ao Tribunal de Justiça que, considerando o risco de danos irreparáveis a direitos fundamentais dos moradores e sua relevância jurídica e social, determinou a suspensão do cumprimento da ordem até o julgamento final do recurso. ${ }^{11}$

A regularização fundiária se apresenta como diretriz vinculante e instituto jurídico e político da política urbana, que tem por objetivo ordenar o pleno desenvolvimento das funções sociais da cidade e da propriedade e garantir o bem estar de seus habitantes, no que se insere a realização do direito à moradia (BRASIL, 2001). O conjunto de medidas jurídicas, urbanísticas, ambientais e sociais que compõem a regularização fundiária têm dentre seus objetivos a garantia do direito social à moradia digna e às condições de vida adequadas, bem como a permanência dos ocupantes e a resolução extrajudicial de conflitos (BRASIL, 2017).

Uma análise sistemática do conjunto de normas constitucionais e legais aplicáveis à política urbana e a regularização fundiária evidencia que o requerimento de instauração da Reurb ou a manifestação de interesse nesse sentido por parte de qualquer dos legitimados garantem aos ocupantes dos núcleos urbanos informais a permanência, preservando-se as situações de fato já existentes, pelo menos até o eventual arquivamento definitivo do procedimento. ${ }^{12} \mathrm{De}$ forma ainda muito mais ressaltada, é evidente o direito de permanência quando o Poder Público competente determina a instauração do procedimento de Reurb, especialmente em se tratando de núcleo urbano informal consolidado ocupado predominantemente por população de baixa renda, onde é inequívoco o interesse social (BRASIL, 2017).

10 O processo tramita junto à Vara Agrária em razão das características rururbanas da comunidade. Contudo, as normas relativas à Reurb se aplicam aos assentamentos humanos com uso e características urbanas, independentemente da propriedade do solo, ainda que situado em área qualificada ou inscrita como rural (art. 11, I, da Lei 13.465/17).

11 A decisão foi proferida monocraticamente pelo Relator em substituição concedendo o efeito suspensivo ao recurso de Agravo de Instrumento 1.0024.15.051252-3/006. Até o fechamento deste artigo não havia sido realizado o julgamento final do recurso.

$12 \mathrm{O}$ art. 31, § $8^{\circ}$, da Lei 13.465/17 é explícito quanto ao direito de permanência desde o requerimento ou manifestação de interesse de instauração da Reurb até o eventual arquivamento definitivo do procedimento aos ocupantes dos núcleos urbanos informais situados em áreas públicas. Contudo, toda a sistemática das normas aplicáveis e o conjunto de interesses públicos e sociais envolvidos exigem a compreensão da aplicação deste entendimento também à áreas privadas. 


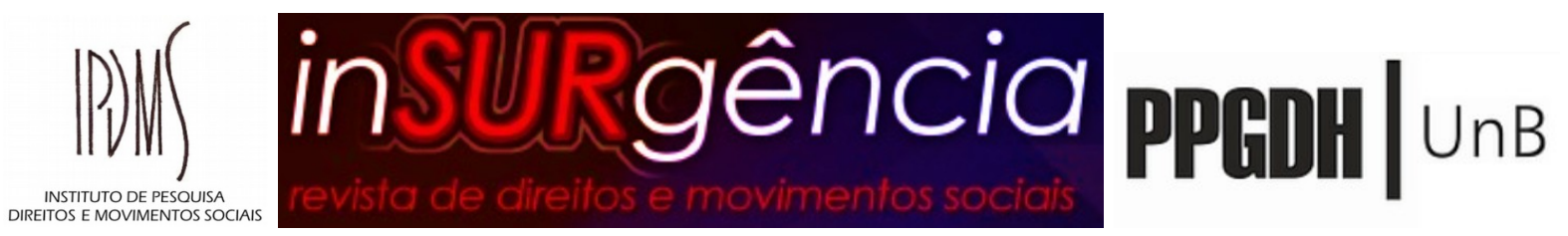

Para além do requerimento, manifestação de interesse ou a própria instauração da Reurb, que por si já devem garantir segurança da posse aos moradores, ${ }^{13}$ ainda existem diversos institutos jurídicos que podem ser empregados para fins de resolução de conflitos e regularização fundiária, em alguns casos inclusive com direitos adquiridos dos moradores. É urgente que os Poderes Públicos, inclusive o Judiciário, compreendam as questões fundiárias para além das políticas públicas discricionárias, mas como garantia concreta de direitos. ${ }^{14}$

\section{2) A OCUPAÇÃO CANDEEIRO E O ABANDONO DE BENS IMÓVEIS}

A ocupação Candeeiro, localizada na cidade de Belo Horizonte/MG, se constituiu em um terreno completamente abandonado e sem uso há décadas, um vazio urbano ilhado em meio à uma zona urbanizada e edificada. O imóvel classificado como Área de Especial Interesse Social-1, ou seja, reconhecido oficialmente como um vazio urbano que deve ser destinado à moradia de interesse social. Contudo, além do abandono do imóvel por décadas, sem posse ou qualquer utilização concreta, mesmo o procedimento do alegado empreendimento que o suposto proprietário afirma pretender fazer no local, se encontra sem qualquer movimentação junto à Prefeitura desde o ano de 2011. Além disso, o imóvel acumula débitos de Imposto Predial e Territorial Urbano (IPTU) desde o ano de 2013, somando uma dívida de mais de $\mathrm{R} \$ 230.000,00$ (duzentos e trinta mil reais). Ou seja, uma situação de evidente descumprimento da função social da propriedade que, pela ausência de posse e descumprimento até mesmo das obrigações tributárias, demonstra o completo abandono do imóvel, retido para fins meramente especulativos.

Atualmente, na comunidade, que se iniciou no ano de 2016, moram cerca de cinquenta famílias que auto construíram suas casas, em regra de alvenaria, com boa estrutura e de forma a integrar a comunidade ao bairro em continuada às vias existentes e de acordo com as características de ocupação da região. As famílias se encontram ainda já integradas às redes de serviços públicos locais, sendo cadastrados e atendidos nos postos de saúde, com as crianças e adolescentes matriculados e frequentando as escolas, bem como se formaram as redes de acesso ao trabalho e à sociabilidade.

13 No caso da ocupação Tomás Balduíno, para além da instauração da Reub-S, foi demonstrado o direitos dos moradores como à desapropriação judicial (art. 1.228, $\S 4^{\circ}$, do Código Civil), à acessão inversa (art. 1.225, parágrafo único, do Código Civil), legitimação fundiária (art. 23, da Lei 13.465/17).

$14 \mathrm{O}$ art. 15 da Lei 13.465/17 apresentam um rol exemplificativo de institutos aplicáveis, sem prejuízo de outros que se apresentem adequados. 


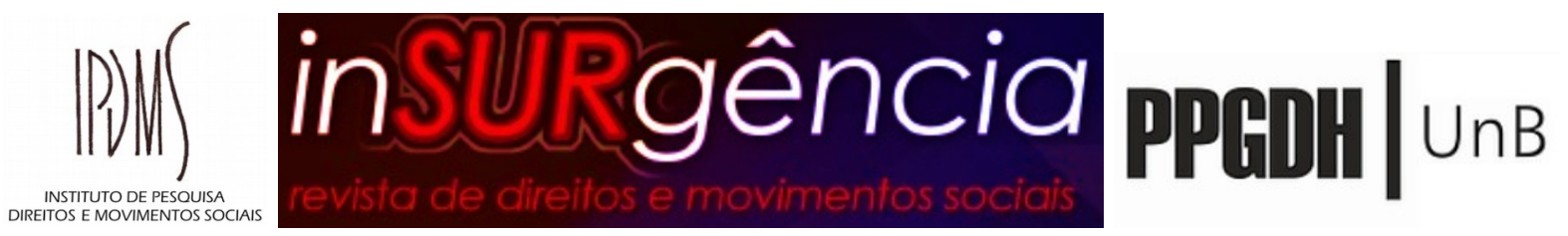

Desde o ano de 2017, a comunidade resiste às tentativas de despejo em razão de um processo de reintegração de posse movido pelo suposto proprietário. Após o deferimento da ordem de despejo foram interpostos recursos pela Defensoria Pública e pelos advogados populares no Tribunal de Justiça que, considerando a especial complexidade do caso e a possibilidade de danos irreparáveis aos moradores, determinou a suspensão do cumprimento da ordem até o julgamento final do recurso. Contudo, em várias oportunidades o Tribunal intentou promover o julgamento final sem a construção de espaços efetivos de diálogo e mediação do conflito com os poderes públicos competentes, anunciando uma forte tendência à retomada da ordem de despejo (TJMG, 1.0000.17.061726/002, 2017).

Os poucos encontros promovidos apenas após muita reivindicação no Centro Judicial de Solução de Conflitos e Cidadania (CEJUSC) sempre se mostraram ineficientes, em razão de uma postura autocentrada do Judiciário que se negava a ampliar a participação nesse espaço para os órgãos públicos responsáveis pela política urbana e habitacional. Diante desse cenário a comunidade, junto com a advocacia popular e a militância das Brigadas Populares, teve de intensificar o desenvolvimento de sua organização comunitária e política para a resistência ao despejo, articulando outros atores e conjugando estratégias de luta.

Acionando a Comissão de Direitos Humanos da Câmara Municipal, com o apoio da Vereadora Bella Gonçalves, a comunidade realizou uma audiência pública, onde, além de demonstrar as contradições da política urbana e habitacionais municipais, exigia um posicionamento do Município sobre o caso. ${ }^{15}$ Diante das reivindicações, o representante da Companhia Urbanizadora e de Habitação de Belo Horizonte (URBEL) colocou sobre as políticas de regularização fundiária do Município e que instrumentos afetos à política habitacional e urbana poderiam se aplicar à comunidade, bem como que, caso regularizada, passaria por vários procedimentos de adequação urbana e que isso envolveria o estabelecimento de acordos com o proprietário do terreno. Como resultado da audiência pública, o Poder Legislativo indicou ao Executivo:

1) declarar o interesse social para fins de regularização fundiária da comunidade;

2) instaurar uma câmara de mediação do conflito fundiário, buscando soluções extrajudiciais, justas e pacíficas para o conflito;

3) promova o cadastro social das famílias, visando conhecer a realidade da comunidade e promover a garantia de seu direito à moradia e aos demais direitos sociais;

15 A audiência pública foi requerida pela Vereadora Bella Gonçalves, pelo Requerimento de Comissão $\mathrm{n}^{\circ}$ 913/2019. 


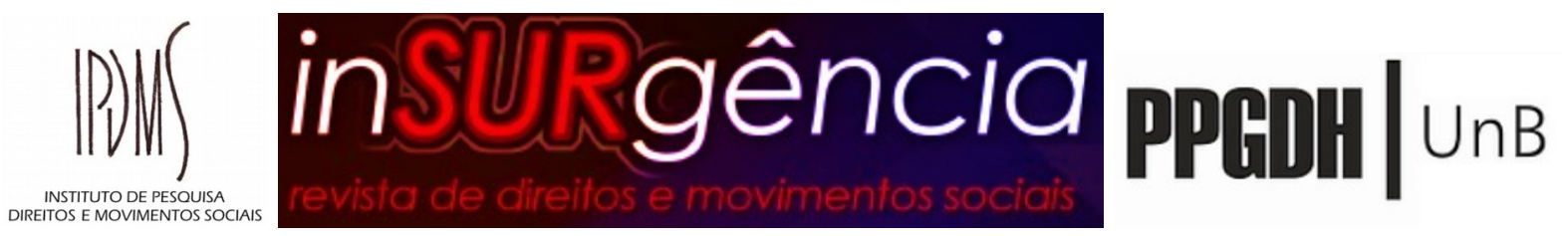

4) designe uma reunião de trabalhos para que se busquem alternativas concretas para resolução do conflito (CMBH, 2019b).

Diante da ausência de retornos e consciente de que os resultados concretos só conquistam com a luta, a comunidade se organizou para exigir do Poder Executivo compromissos e respostas efetivas, ocupando a entrada da sede da URBEL reivindicando uma reunião com a Presidência da Companhia. Nesse contexto, em reunião com a comunidade, os advogados populares e o Ministério Público, a URBEL se comprometeu a realizar o cadastramento socioeconômico das famílias e a compor as tratativas nas instâncias de mediação do conflito e buscar soluções para sua resolução. ${ }^{16}$

Os fatos novos sobre o posicionamento dos órgãos públicos municipais foram levados à conhecimento da Justiça pela advocacia popular previamente a uma sessão de julgamento onde se anunciava a retomada do despejo. Mesmo com entraves impostos por Desembargadores até mesmo ao uso da palavra pelos advogados populares na sessão, foi exposto o contrassenso em se promover o julgamento, e especialmente em se decidir pelo despejo, sem considerar a posição dos Poderes Públicos municipais sobre o caso diante da luta da comunidade. Diante de todas as negativas do Judiciário em ampliar a participação no tratamento do conflito para os órgãos públicos responsáveis pela política urbana e habitacional e tendo estes se posicionado em razão luta da comunidade, exigia-se uma posição juridicamente adequada dos julgadores.

Nesse contexto, foi realizado o pedido de vista por um dos Desembargadores que, em uma postura contrastante com o habitual conservadorismo do Judiciário, determinou a realização de uma “inspeção/visita” judicial na comunidade, fundamentando ser necessário conhecer a realidade sobre qual trata a causa e melhor embasar o posicionamento a ser adotado quanto ao mérito. Na visita estiveram presentes dois Desembargadores, membros do Ministério Público, da Defensoria Pública e da Comissão de Direitos Humanos da Câmara Municipal, da URBEL, além dos moradores, os advogados populares, assessoria técnica da comunidade e representantes de centros comunitários locais. No relatório da visita, junto com um amplo registro fotográfico, consta o que foi verificado no local, especialmente sobre as casas autoconstruídas preponderantemente em mutirão, em alvenaria e mobiliadas, estruturadas conforme as particularidades e diversidades familiares, algumas com hortas e

16 Na reunião, a URBEL levantou a possibilidade de realizar estudo técnico de aproveitamento de um terreno que poderia ser oferecido pela Companhia de Habitação de Minas Gerais (COHAB) em permuta do imóvel ocupado e de alterar seu zoneamento que possibilitando melhor aproveitamento e uso produtivo da área, sem prejuízo de outras alternativas viáveis de resolução do conflito. 


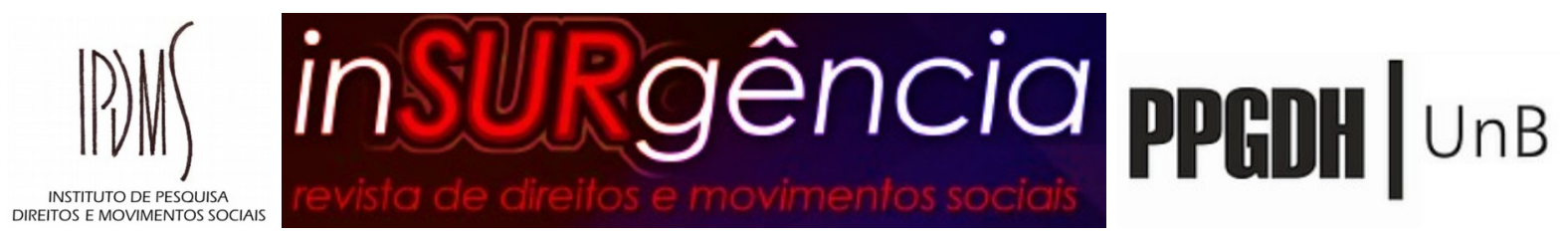

jardins. Também sobre a inserção das crianças e adolescentes nas escolas locais, os suportes à comunidade pelos equipamentos de creches e centros comunitários, bem como as redes de trabalho dentro e para além da comunidade. Ainda consta sobre os primeiros ocupantes vieram da expansão da população da Vila Embaúbas, já regularizada e vizinha do terreno, que a área da ocupação é uma AEIS e a região é composta majoritariamente por diversas comunidades de baixa renda, que são objeto de estudos e projetos de regularização fundiária. O relatório conclui que o imóvel não apresenta sinais de ocupação anterior e, hoje, se destina à moradia de mais de cinquenta famílias e duzentas pessoas, com sentimento de integração e pertencimento ao local e esforços e cuidados em busca da legitimação de seu direito à moradia, cumprindo sua função social. Finaliza, com fotografias da cidade e das montanhas da capital mineira, registrando que "de lá avistam um belo horizonte”.

Os registros constantes no relatório de visita demonstram que, embora a realidade não caiba em documentos judiciais, as diversas estratégias de luta podem influenciar na condução dos processos e proporcionar posicionamentos mais próximos e adequados ao mundo do vida. Espera-se uma posição final do Judiciário que seja pelo reconhecimento dos direitos da comunidade ou, ao menos, da necessidade de uma mediação efetiva do conflito, entendendo sua complexidade e envolvendo todos os interessados e os Poderes Públicos competentes para a construção de uma solução garantidora de direitos. ${ }^{17}$

A perspectiva da resolução de conflitos fundiários e de realização da regularização fundiária como garantia de direitos depende de uma compreensão conjugada de diversos aspectos, inclusive sociais, jurídicos e urbanísticos. Essa perspectiva só pode ser construída diante da realidade concreta e de suas repercussões jurídicas e políticas, necessariamente construídas em ampla interlocução entre os atores sociais e públicos para a tomada de decisões.

Nos conflitos que envolvem a propriedade e a posse, a solução deve se dar pela avaliação concreta do cumprimento da função social de ambos os direitos. Ainda, para além das normas propriamente possessórias, a legislação brasileira há tempos já reconhece que, em se tratando de imóvel urbano, cessados os atos de posse e deixando o proprietário de satisfazer os ônus fiscais, presume-se de forma absoluta o abandono, que é hipótese de perda da propriedade ${ }^{18}$. Em conflitos fundiários, a perda da propriedade, decorrente exatamente da

17 Até o fechamento deste artigo não havia sido realizado o julgamento final do recurso nem sido encaminhado a instâncias de mediação.

18 A perda da propriedade pelo abandono já era reconhecida pelo Código Civil de 1916 (art. 589, III, e § 2º), o que se manteve no Código Civil de 1916 (art. 1.275, III, e art. 1.276). A Lei 13.465/17 trouxe maior 


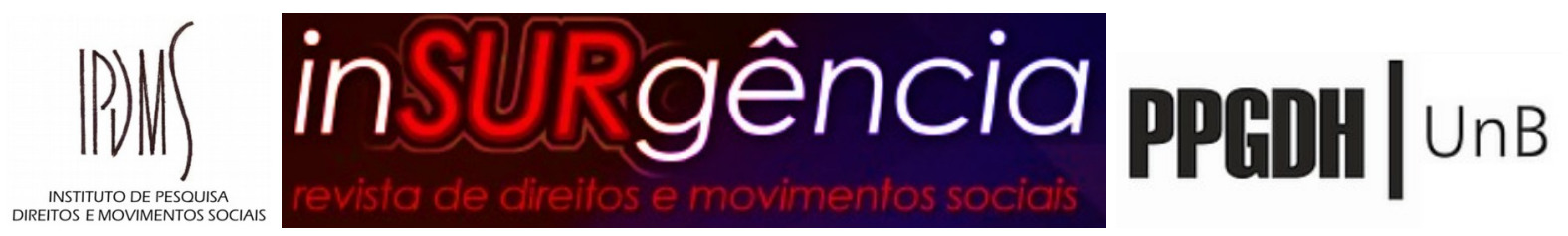

ausência de posse e do cumprimento das obrigações tributárias, por si só, já é elemento suficiente para garantia da segurança da posse dos ocupantes pelo instituto jurídico próprio do abandono. O reconhecimento e aplicação do direito nesses casos pode ser realizado pelo Poder Judiciário com eficácia declaratória da situação de fato, como forma de resolução judicial do conflito, sem prejuízo da atuação dos demais Poderes Públicos.

Contudo, em se tratando de imóvel urbano abandonado que esteja ocupado por população de baixa renda para fins de moradia, para além do reconhecimento da perda da propriedade como instituto jurídico de segurança da posse na resolução do conflito fundiário, compete ao Poder Público Municipal promover a arrecadação do imóvel e destiná-lo à Reurb$\mathrm{S}^{19}$ como instituto jurídico de regularização fundiária (BRASIL,2017). A resolução de conflitos fundiários e a realização da regularização fundiária dependem de um conjunto de medidas que apresentam contornos jurídicos e políticos que devem ser considerados pelos agentes sociais e públicos na luta pela a garantia de direitos.

\section{3) A OCUPAÇÃO VICENTÃo E A LUTA PELO DIREITO AO CENTRO}

Vai flor se florindo no coração renasce pra sobreviver uma nova ocupação! Composta de amor carinho fé e união veio a viver conosco o guerrilheiro Vicentão. Vai, vai em frente! Povo sem medo, sem medo de arriscar, colocando a cara a tapa pra conseguir um lar. Punhos erguidos, plantou a lutar. Pra viver a liberdade que um dia vai chegar (Mariana Karen - moradora da ocupação)

A Ocupação Vicentão realizada no centro da cidade de Belo Horizonte, capital de Minas Gerais, buscou articular a luta por moradia digna, a luta pelo direito da periferia ocupar o centro e a luta pelo direito ao trabalho de ambulante nas ruas da cidade criando uma identidade coletiva que agregou 90 (noventa) famílias que retomaram um imóvel ocioso para lhe dar destinação social.

O nome Vicentão, foi uma referência ao advogado popular Vicente Gonçalves, homem negro e uma das principais lideranças faveladas da cidade. Ele faleceu em 2016, aos 83 anos, dos quais 70 foram dedicados às lutas sociais. O advogado atuou desde o início da adolescência quando aos 13 anos participou de um processo de resistência a um despejo na Vila Querose, em Belo Horizonte, local em que morava e que juntamente com crianças e adolescentes chegou a resistir a um despejo a ser realizado pela Polícia Militar com

regulamentação ao instituto (art. 64 e art. 65).

19 Art. 15, IV, e art. 65 da Lei 13.465/17. 


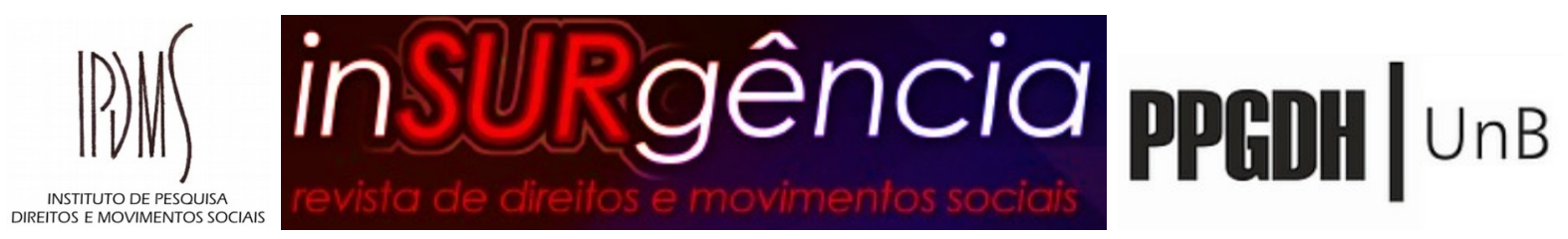

“botoques” (VASCONCELOS DE FREITAS, 2015). Lutou pelos favelados, com as ocupações e por Justiça de Transição tendo enfrentado a ditadura civil e militar de 19641985.

A referida ocupação aconteceu no dia 12 de Janeiro de 2018 e foi realizada por pessoas sem-teto e trabalhadores ambulantes que haviam sido proibidos de trabalhar nas ruas do centro da cidade e sofreram forte repressão policial, em julho de 2017, tendo o aparato repressivo se utilizado até mesmo do “Caveirão" - veículo blindado do Comando de Policiamento Especializado (CPE) da Polícia Militar de Minas Gerais (PMMG). O instrumento da operação urbana consorciada simplificada estava para ser aplicado pela Prefeitura de Belo Horizonte de maneira a retirar os trabalhadores das ruas e inaugurar “shoppings populares” gerenciados pelo empresariado local. Produziu-se um cenário de guerra no centro da cidade de Belo Horizonte e, na ocasião, dezenas de pessoas ficaram feridas e várias pessoas presas (MIRANDA; VASCONCELOS DE FREITAS, 2017).

O imóvel ocupado, um prédio de 10 andares, é repleto de embaraços judiciais que envolvem débitos com a Fazenda Pública de Belo Horizonte e a Fazenda Nacional, dentre outros. Só os débitos de Imposto Predial Territorial Urbano (IPTU), quando da ocupação, somavam as competências em aberto dos anos de 2002, 2003, 2005, 2006, 2007, 2014, 2015, 2016, 2017 e 2018. O proprietário do imóvel era o banqueiro falecido Tasso Assunção, o primeiro condenado por crime de colarinho branco no Brasil e responsável por lesar centenas de clientes e trabalhadores por via de esquemas fraudulentos envolvendo o Banco Hércules e o Consórcio Mercantil. Foragido da Justiça, ele se escondia em um cômodo que ficava atrás de um armário em sua mansão no bairro Cidade Jardim. O imóvel estava abandonado há anos em função da inoperância e por especulação imobiliária da massa falida e do Poder Judiciário onde há anos tramita o processo de falência do Banco Hércules.

No dia 13 de março de 2018 Cláudio Araújo de Assunção Costa, na qualidade de inventariante do Espólio e herdeiro de Tasso Assunção Costa, interpôs petição simples nos autos do processo de falência do Banco Hércules S.A., em nítido desrespeito ao procedimento autônomo de reintegração de posse que permitiria o exercício do direito ao contraditório e ampla defesa aos ocupantes, requerendo a reintegração forçada por suposto ato de "invasão" do prédio arrecadado no processo de falência.

Garantir o direito ao contraditório e ampla defesa é assegurar o devido processo legal como o direito dos ocupantes a um processo justo formado como instrumento de defesa diante 


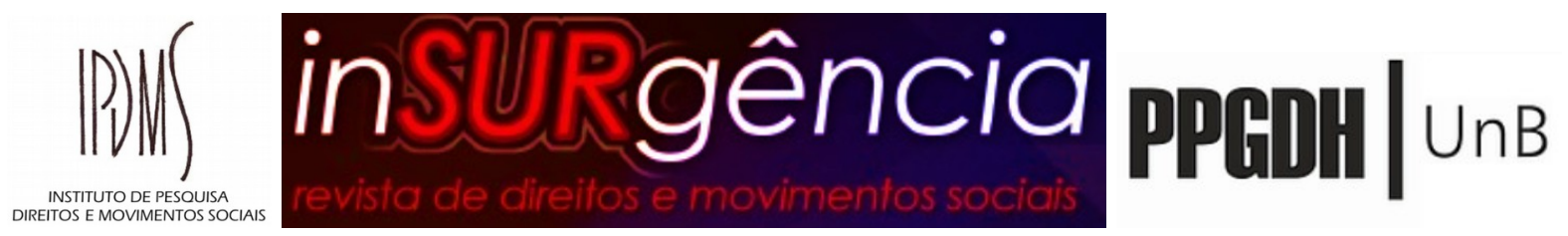

do exercício abusivo do poder e como instrumento de efetivação dos direitos sociais dos moradores. Assim, o direito de participação e de poder influir no processo judicial nascia comprometido.

A ocupação reivindicava o direito ao centro como expressão do direito à cidade, o direito a uma vida urbana, transformada e renovada, uma vida digna (LEFEBVRE, 2011). Assim, a ocupação teve o objetivo de reivindicar um lugar dotado de infraestrutura, com rede de água e de esgoto, energia, internet, hospitais, postos de saúde, parques, praças, ruas, acesso à renda, ônibus, metrô. Em oficina com as crianças da ocupação surgiu a seguinte letra que sintetiza essa disputa política pelo direito ao centro: “No coração de BH/Aqui vou ficar/Aqui é meu lugar/com casa pra morar/sem ninguém para nos parar/Então não vem não /Que aqui é a Ocupação do Vicentão/ Não tem preguiça não”.

No dia 24 de abril de 2018 o juiz Adilon Cláver de Resende, da 2a vara Empresarial de Belo Horizonte, determinou a expedição de mandado de reintegração de posse em decisão reduzida a um parágrafo, sem fundamentação, em meio à outros despachos de rotina do trâmite falimentar. No dia 26 de junho de 2018 o Desembargador Marcelo Rodrigues, da $2^{\text {a }}$ Câmara Cível do Tribunal de Justiça de Minas Gerais, acolhendo pedido de advogados populares da ocupação se manifestou da seguinte forma:

\footnotetext{
No caso dos autos, aliás, o magistrado de primeira instância acolheu as alegações do depositário fiel com, apenas, um único parágrafo:

'1. Diante das informações trazidas pelo depositário fiel Cláudio Araújo de Assunção Costa, às fls. 10.757/10.761, de que o imóvel localizado na Rua Espírito Santo, $n^{\circ}$ 461, Centro, nesta Capital, foi invadido pela "Ocupação Vicentão" no dia 12 de janeiro de 2018, expeça-se, com urgência, mandado de reintegração de posse, uma vez que o bem foi arrecadado nesta falência e encontra-se na posse do requerente, até que seja ultimada a venda do bem'.

Ora, nem mesmo os tais ocupantes foram ouvidos (cujo número nem se sabe precisar). As famílias que atualmente residem naquele imóvel, então, estão diante de verdadeira vulnerabilidade e desamparo. Vulneráveis porque já vislumbradas como humildes e necessitadas socialmente, desamparadas porque sem qualquer direito na decisão proferida (TJMG, 1.0024.02.683314-5 (001), 2018).
}

A decisão judicial acima abriu espaço para a distensão do conflito em um processo de mediação do conflito fundiário estabelecido na Mesa Estadual de Diálogo e Negociação Permanente com Ocupações Urbanas e Rurais e outros grupos envolvidos em conflitos socioambientais e fundiários. A Mesa de Diálogo foi instituída por meio do Decreto $\mathrm{n}^{\circ}$ 203, de $1^{\circ}$ de Julho de 2015, com alterações feitas pelo Decreto $\mathrm{n}^{0}$ 520, de 28 de Setembro de 2016, do então Governador de Minas Gerais - Fernando Pimentel (PT) - com o objetivo 


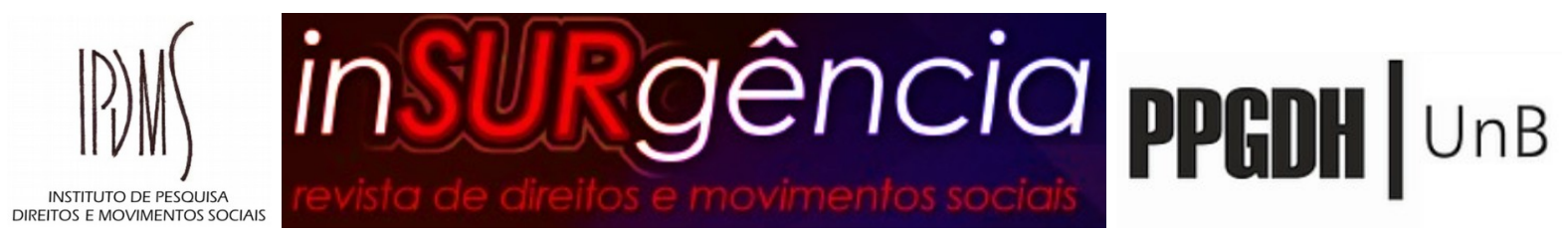

inicial de mediar e solucionar conflitos fundiários de luta pela terra e pela moradia, em todo o estado de Minas Gerais.

A Mesa de Diálogo foi um importante instrumento de mediação de conflitos fundiários, criado por um Decreto do Poder Executivo, mas a partir de lutas dos movimentos sociais que realizaram trancamentos de vias, seminários, manifestações que levaram à instituição desse espaço (JESUS et al, 2019). Em reuniões de mediação os moradores da ocupação, advogados populares e representantes do movimento social envolvido levantaram a necessidade de aplicação dos instrumentos de política urbana incluídos os instrumentos previstos na Lei 13.465/2017. A instalação de REURB-S, a demarcação urbanística com reconhecimento do núcleo urbano informal e a legitimação da posse foram levantadas como possibilidades de intervenção, bem como a arrecadação de imóvel abandonado como forma de combater os vazios urbanos no centro, mas a Prefeitura de Belo Horizonte adotou uma postura de não assumir nenhum compromisso diante do conflito instalado.

No dia 28 de dezembro de 2018 a Ocupação Vicentão realizou um acordo com a Companhia de Habitação do Estado de Minas Gerais (COHAB-MG), assinado na "Mesa de Negociação” e previa o pagamento de bolsa aluguel por 02 (dois) com o reassentamento em áreas de regularização fundiária em seguida. A Luta das famílias conquistou o direito ao centro e fortaleceu a economia popular, com o início das atividades do Centro de Apoio ao Trabalhador Ambulante (CATA) que hoje se encontra funcionando em outra área do centro mobilizando trabalhadores informais que atuam no centro como pipoqueiros, fruteiros, toreiros e caixeiros. O CATA tornou-se um espaço popular e ponto de apoio localizado em Belo Horizonte (MG), destinado à articulação e organização dos trabalhadores e trabalhadoras de rua, ambulantes, autônomos e camelôs. Os trabalhadores e trabalhadoras continuam em luta após descumprimentos do acordo por parte do Governo de Romeu Zema.

\section{4) AS OCUPAÇÕES DE TIMÓTEO E A LEGITIMAÇÃO FUNDIÁRIA}

O Município de Timóteo, em Minas Gerais, é integrante da Região Metropolitana do Vale do Aço, onde o processo de urbanização recente e acelerado desde a década de 1940 se deu em razão da intensificação da atividade siderúrgica. A siderurgia se iniciou antes mesmo da emancipação do Município, ocorrida cerca de 20 anos mais tarde, ficando a cidade popularmente conhecida como Acesita, nome da primeira empresa de exploração siderúrgica da região. Num processo de urbanização vinculado ao de industrialização se reproduzem as 


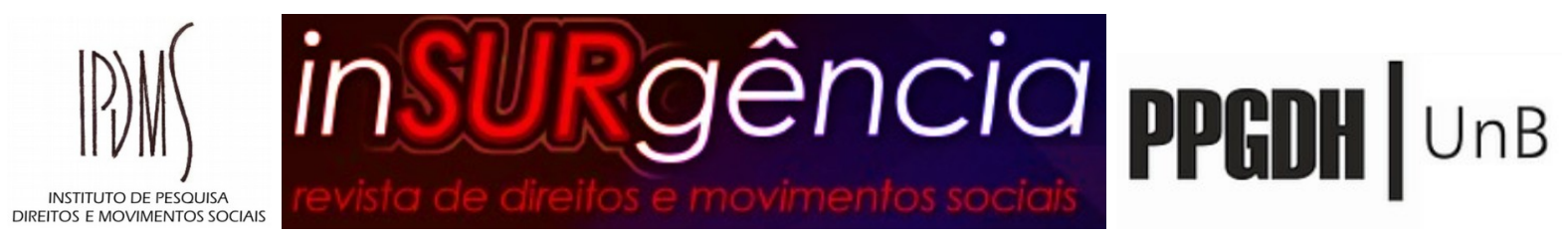

desigualdades e precariedades urbanas, que atingem de forma mais profunda a população mais pobre, com grandes dificuldades no acesso à moradia adequada pelas vias do mercado e diante das ausências de efetivas políticas habitacionais municipais. ${ }^{20}$

Nesse contexto, ao longo do ano de 2012 se formaram as ocupações conhecidas como ocupação do Posto, Massaranduba, Bálsamo, Pinho de Riga, Canela, Ébano, Macuco e da Igreja Católica. A primeira, com cerca de 40 famílias se constituiu em um terreno baldio privado, próximo a um posto de gasolina que inspirou seu nome entre os moradores locais, um vazio repleto de mato em meio à zona urbana de um bairro popular. As demais, com cerca de 400 famílias, se constituíram em áreas públicas municipais sem utilização em diferentes localidades próximas, também em bairros populares vizinhos.

No caso da ocupação do Posto, o terreno foi reivindicado por seu suposto proprietário em uma ação de reintegração de posse (TJMG, 0046309-04.2012.8.13.0687, 2012). Após várias audiências de justificação e emendas à petição inicial, mesmo diante da ausência de provas e de vícios processuais, o Juízo da Comarca de Timóteo deferiu a liminar determinando o despejo. Levada a questão ao Tribunal, foi suspensa e posteriormente revogada a liminar, à unanimidade, exatamente pela ausência de prova da posse anterior do suposto proprietário. Dando seguimento ao processo e produzidas provas, mesmo com a insuficiência e contradições entre as provas do autor e mediante cerceamento de defesa dos moradores, o Juiz determinou a reintegração de posse em sentença. Levada também a questão ao Tribunal, foi anulada a sentença por cerceamento de defesa, em razão do indeferimento ilegal da oitiva das testemunhas dos moradores tendo os autos voltado à $1^{\mathrm{a}}$ instância e após colhida prova testemunhal comprovatória do abandono do imóvel sobreveio nova sentença reintegratória. Em novo recurso de apelação o Tribunal resolveu por manter a sentença de despejo, em uma sessão de julgamento realizada em condições contrárias ao devido processo legal.. ${ }^{21}$

20 No Município de Timóteo 34,6\% da população possui um rendimento nominal mensal per capita de até 1/2 salário mínimo. IBGE - cidades @. Disponível em: https://cidades.ibge.gov.br/brasil/mg/timoteo. Acesso em: 23 maio 2020).

21 Embora a $18^{\mathrm{a}}$ Câmara Cível tenha revogado a liminar ao argumento da ausência de posse anterior do autor da ação, quando da análise da apelação contra sentença, com nova composição, a Câmara decidiu pelo despejo. Contudo, o que causa maior estranheza foi a forma do julgamento, uma vez que este ocorreu em sessão presencial durante o período em que o processo se encontrava com prazo suspenso e no qual eram vedadas a realização desse tipo de ato em razão das medidas vigentes de isolamento social para contenção da grave pandemia da Covid-19. Apesar das diversas manifestações contrárias dos advogados populares, foi realizado o julgamento na sessão de 14/07/2020, contrariamente ao devido processo legal e determinando o despejo das famílias em plena crise sanitária, econômica e política. Até o fechamento deste artigo se encontravam pendentes 


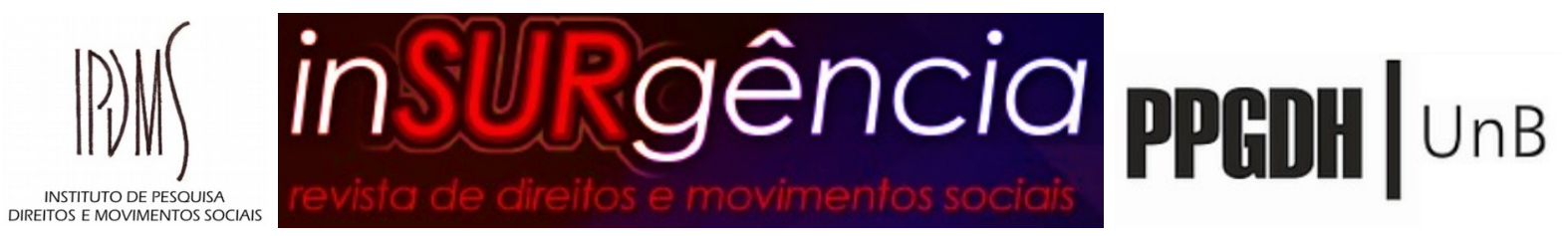

Já no caso das ocupações Massaranduba, Bálsamo, Pinho de Riga, Canela, Ébano, Macuco e da Igreja Católica, após violentas e frustradas tentativas de despejo com aparato policial, os terrenos foram reivindicados por ação de reintegração de posse proposta pelo Município de Timóteo (TJMG, 0023035-11.2012.8.13.0687, 2012). O Juiz da comarca de Timóteo deferiu a liminar determinando o despejo, que foi suspenso pelo Tribunal de Justiça poucas horas antes do cumprimento. Contudo, posteriormente o Tribunal indeferiu o recurso, retomando a vigência da ordem de despejo, que só foi novamente suspensa por recursos posteriores. Também foi interposta ação civil pública pela Defensoria Pública do Estado de Minas Gerais com objetivo de obrigar o Estado e o Município a garantirem a permanência das famílias mediante a regularização fundiária a urbanização da área (TJMG, 003192196.2012.8.13.0687, 2012). A ação de reintegração de posse e a ação civil pública foram declaradas conexas e em sentença foi determinado o despejo, confirmando a antecipação dos efeitos da tutela com prazo de sessenta dias para cumprimento pela Polícia Militar e, contraditoriamente, que o Município e o Estado promovessem a inclusão dos moradores com renda de 0 (zero) a 3 (três) salários mínimos em programas habitacionais, desde que preenchidos os respectivos requisitos legais, no prazo de 90 (noventa) dias contados do trânsito em julgado, ou seja, com o despejo para se realizar antes da inclusão nos programas habitacionais. ${ }^{22}$ Interposto recurso de apelação, o Juiz se manteve inerte em promover o juízo de admissibilidade, impedindo a concessão de efeito suspensivo, que só foi obtido por meio de uma cautelar inominada junto ao Tribunal ainda sob a vigência do Código de Processo Civil de 1973 (TJMG, 0819134-21.2015.8.13.0000, 2015). Todas as ações conexas dependem de julgamento final pelo Tribunal de Justiça.

Embora se trate de oito ocupações localizadas em áreas distintas e próximas umas das outras e com diferentes reivindicantes dos imóveis, as comunidades sempre conceberam que a luta era uma só. Vários apoios importantes se formaram em defesa das ocupações, a exemplo dos posicionamentos encaminhados ao Município pelo Conselho Estadual de Defesa dos Direitos Humanos (Conedh), pelo Instituto de Pesquisa, Direitos e Movimentos Sociais

os recursos cabíveis.

22 Tão obstinado o Juiz em promover o despejo que o prazo para sua realização era de 60 dias e em caso de não cumprimento fixou multa diária de R\$10.000,00 (dez mil reais), em desfavor do Estado de Minas Gerais, sem limitação temporal, em favor do Município de Timóteo/MG. Já para a inclusão nos programas habitacionais o prazo era de 90 dias contados somente após o trânsito em julgado em uma sentença sujeita à remessa necessária e em caso de não inclusão das famílias que preenchessem os respectivos requisitos legais fixou multa diária de R\$1.500,00 (um mil e quinhentos reais), limitada à 30 (trinta) dias. Ou seja, conforme sua determinação, além da desproporção das muitas, muito mais elevada para garantir o despejo, este inevitavelmente deveria ocorrer antes da inclusão nos programas habitacionais. 


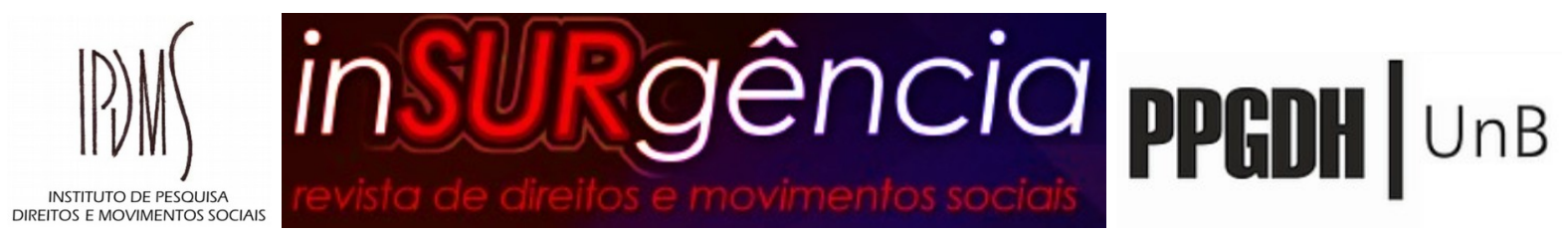

(IPDMS) e pela Relatora Especial para o Direito à Moradia Adequada da Organização das Nações Unidas (ONU) Raquel Rolnik. Sob o grito de ordem de que “mexeu com uma, mexeu com todas”, a organização e a luta política coletiva, com grandes atos e passeatas unificados entre as comunidades e inclusive com apoio de ocupações organizadas de outras cidades, foram instrumentos fundamentais na resistência ao despejo e na luta por regularização. ${ }^{23}$

Diante das pressões das ocupações, a Prefeitura então se abriu para a possibilidade do diálogo. As tratativas começaram a ser feitas a perspectiva e as propostas da comunidade se deram para além de uma mera resolução do conflito fundiário, apontando também para as possibilidades de regularização fundiária. Buscando apoios políticos para fortalecer essa movimentação, as comunidades e as Brigadas Populares conseguiram a designação pela Deputada Estadual Andreia de Jesus de emenda parlamentar orçamentária de efeito impositivo da Assembleia Legislativa do Estado de Minas Gerais destinando recursos para regularização fundiária das ocupações pelo Município de Timóteo. ${ }^{24}$

Embora se entendesse mais adequado tratar da resolução do conflito na Mesa de Diálogo do Estado, como forma de proporcionar maior envolvimento de outros entes e órgãos públicos, o Tribunal adotou o entendimento de que as tratativas deveriam se dar no CEJUSC. A advocacia popular então encaminhou uma proposta de acordo à Prefeitura em uma perspectiva de resolução do mérito do conflito associada à regularização fundiária plena. Contudo, em reunião do CEJUSC, a Prefeitura, representada apenas por advogados e sob o abstrato argumento jurídico da indisponibilidade do patrimônio público, afirmou que não poderia firmar o acordo.

A posição da Prefeitura, além de contrariar as tratativas políticas até então realizadas, desconsiderava a própria legislação de regularização fundiária vigente, que respaldava juridicamente a possibilidade do acordo, defendido não apenas pela advocacia popular, como também pelo Ministério Público e chancelado pelo Judiciário na pessoa dos seus membros presentes. Diante do impasse, ficou entendido pelo encaminhamento do caso à Mesa de Diálogo, no sentido de possibilitar a continuidade das tratativas com vistas à resolução do conflito e à regularização fundiária das comunidades. ${ }^{25}$

Fica evidente que, mesmo quando a luta consegue superar obstáculos políticos estruturais para o reconhecimento do direito das comunidades, inclusive com apoio

23 Destaca-se que ao longo de oito anos de luta, o Município chegou a ter cinco prefeitos em razão de cassações ocorridas, o que impacta da estabilidade política municipal e na luta da comunidade.

24 A emenda parlamentar impositiva aprovada de autoria da Deputada Estadual Andreia de Jesus.

25 Até o fechamento deste artigo não havia sido realizada reunião da Mesa de Diálogo para a tratativa do caso. 


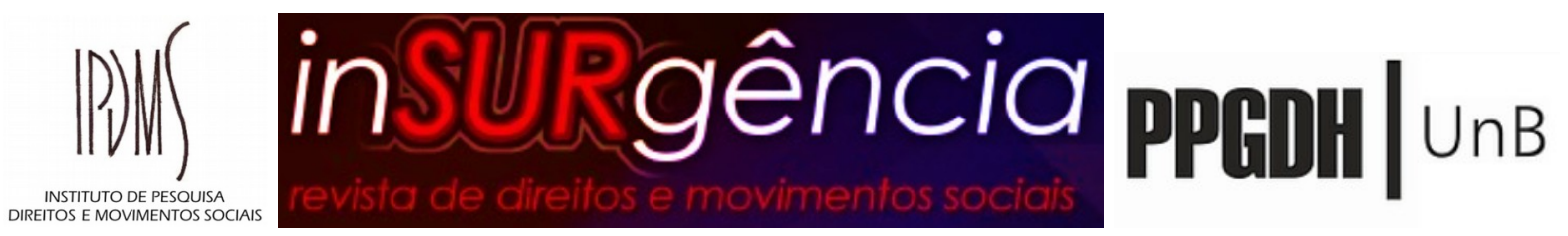

parlamentar e dos órgãos do sistema de justiça, os discursos jurídicos, ainda que desconsiderando o direito aplicável, podem se prestar a fundamentar posições conservadoras de seus operadores ou de quem representam. Embora o direito apresente possibilidades de seu uso estratégico para a luta, suas contradições sempre possibilitam também os discursos de retrocesso. Deve-se considerar que só o aprofundamento da organização e da luta são capazes de promover os avanços concretos e a transformação de interpretações jurídicas e de comportamentos políticos.

A valoração da função social concreta para resolução de conflitos fundiários que envolvem a propriedade e a posse deve-se aplicar em se tratando sobre imóveis privados ou públicos. Contudo, ainda há outros institutos que devem ter a sua interpretação disputada. A Lei 13.465/17 instituiu a legitimação fundiária, que constitui forma originária de aquisição do direito real de propriedade conferido por ato do poder público, àquele que detiver em área pública ou possuir em área privada, como sua, unidade imobiliária com destinação urbana, integrante de núcleo urbano informal consolidado existente em 22 de dezembro de 2016 (BRASIL 2017).

Em uma interpretação que valorize a realização dos fundamentos e objetivos da República e dos direitos fundamentais, em atenção às exigências sociais, deve-se compreender o instituto como voltado à garantia do direito à moradia e à cidade dos pobres urbanos. Uma vez que se trate de núcleo urbano informal consolidado, ou seja, aquele de difícil reversão, considerados o tempo da ocupação, a natureza das edificações, a localização das vias de circulação e a presença de equipamentos públicos, entre outras circunstâncias (BRASIL 2017), existente em 22 de dezembro de 2016, deve-se reconhecer o direito adquirido à regularização fundiária.

No caso das ocupações de Timóteo, são anos de luta e consolidação desde 2012, com moradias construídas em boa qualidade e em alvenaria, com modelos de arruamento adequados e conforme os padrões de bairros populares, inclusive com nomeação e numeração de ruas. Redes autoconstruídas para instalações de água, luz e esgoto, acesso e integração dos moradores aos serviços de educação, saúde e assistência e aos acessos de trabalho são elementos conquistados pela comunidade. Além disso, existe forte articulação comunitária e vínculos de solidariedade e comunidade construídos na luta pela concretização dos direitos de 


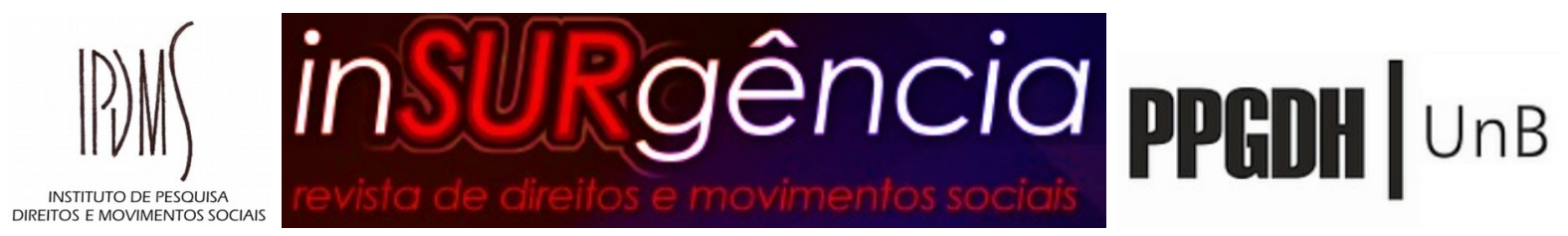

todos. ${ }^{26}$ Diante da realidade concreta, deve-se compreender o direito não como empecilho, mas sim como instrumento de realização das necessidades e das exigências sociais.

\section{5) CONCLUSÃO}

Buscou-se no artigo apresentar uma leitura da publicação da Medida Provisória 759, convertida na Lei 13.465/2017, como fruto de um contexto de Golpe no Brasil ocorrido em 2016 e que através de uma nova legislação de regularização fundiária procurou atribuir títulos de propriedade de imóveis localizados em áreas informais como maneira de aquecer a economia.

Passou-se à análise da questão urbana a partir da necessidade de uma leitura do direito à cidade considerando-se as relações sociais capitalistas que formam uma sociabilidade urbana fundada em relações mercantilizadas do espaço urbano que reforçam a desigualdade social.

As lutas por Reforma Urbana consolidaram uma legislação referência em Política Urbana positivada da Constituição Federal de 1988 e em legislações posteriores como o Estatuto das Cidades, mas a luta pelo Direito à Cidade deve englobar uma articulação de formas políticas que ultrapassam a dimensão reivindicativa de recursos do Estado para estabelecer também uma forma de operação contra o Estado e para além dele como maneira de aglutinar sujeitos em torno de uma pauta coletiva.

A situação de informalidade e de privação aos direitos urbanos, a mercantilização do direito à moradia, às ameaças de despejo forçado colocam a organização política e a luta por direitos como fundamentais no processo de efetivação do direito à cidade para amplas parcelas da sociedade. A institucionalidade deve ser permeada pela luta política que movimenta as estruturas dos Poderes Executivo, Legislativo e Judiciário buscando uma mediação de conflitos fundiários que efetive direitos no espaço urbano.

Para apresentar os limites e possibilidades da aplicação da legislação de regularização fundiária foram narrados casos concretos envolvendo a prática da advocacia popular pelos autores à ocupações urbanas em Minas Gerais que conjugaram diversos

26 Os elementos sobre a estruturação territorial e social da comunidade se encontram também relatados em documentos produzidos pelo Programa Diálogos Comunitários e pela Associação Arquitetas Sem Fronteiras (ASF Brasil), ambos em cooperação técnica com o Centro de Apoio Operacional das Promotorias de Justiça de Defesa dos Direitos Humanos e Apoio Comunitário (CAO-DH) e juntados ao processo. 


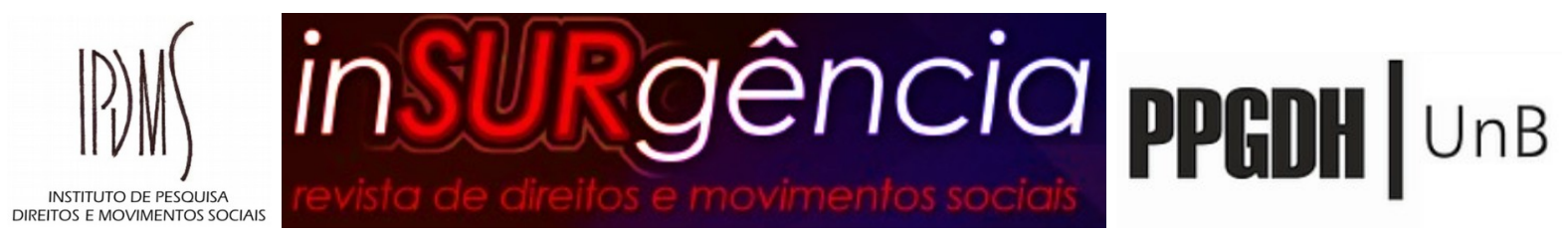

mecanismos de interpretação, aplicação e efetivação de direitos e instrumentos fundiários para moradores de áreas informais.

Mostrou-se como a luta coletiva das ocupações Tomás Balduíno, Candeeiro, Vicentão e comunidades de Timóteo mobilizam atores do sistema de justiça, dos Poderes Legislativo, Judiciário e Executivo para uma mediação de conflitos fundiários que faça prevalecer a função social da posse e da propriedade perante um contexto de mercantilização das cidades e dos direitos urbanos.

Pela análise dos casos concretos conclui-se que a luta pelo direito à cidade tornase um importante instrumento de organização política que busca superar a negação de direitos no espaço urbano. Procuram também superar as limitações dos poderes públicos em gerir uma cidade mais justa por meio da construção de uma sociabilidade urbana constituída pela ação direta de sujeitos que se forjam como protagonistas do direito à cidade.

\section{REFERÊNCIAS BIBLIOGRÁFICAS}

BAHIA, Alexandre Gustavo Melo Franco de Moraes; MEYER, Emílio Peluso Neder; BACHA E SILVA, Diogo; CATTONI DE OLIVEIRA, Marcelo Andrade; VECCHIATTI, Paulo Roberto Iotti. Golpe Vergonhoso passa na Câmara. In: Empório do Direito, São Paulo, 19 de abril de 2016. Disponível em: https:/emporiododireito.com.br/leitura/golpevergonhoso-passa-na-camara-por-alexandre-gustavo-melo-franco-de-moraes-bahia-emiliopeluso-neder-meyer-diogo-bacha-e-silva-marcelo-andrade-cattoni-de-oliveira-e-pauloroberto-iotti-vecchiatti. Acesso em: 20 maio 2020.

BELO HORIZONTE. Câmara Municipal. Indicação nº 164/2019.

BELO HORIZONTE. Câmara Municipal. Requerimento de Comissão nº 913/2019.

BRASIL. Constituição da República de 1988, art. 5, XXIII; art. 6º caput; art. 30, VIII; art. 170, III; art. 182: promulgada em 5 de outubro de 1988. 4. ed. São Paulo: Saraiva, 1990.

BRASIL. Exposição de motivos da Medida Provisória 759, de 21 de dezembro de 2016. Disponível em: http://www.planalto.gov.br/ccivil 03/ ato2015-2018/2016/Exm/Exm-MP \%20759-16.pdf. Acesso em: 29 abr. 2020.

BRASIL. Senado $2017 . \quad$ Federal, Disponível em: http://www12.senado.leg.br/noticias/videos/2017/04/relator-da-mp-759-explica-beneficiosda-regularizacao-fundiaria . Acesso em: 29 abr. 2020.

BRASIL. Código Civil de 1916. art. 589. Disponível em: http://www.planalto.gov.br/ccivil 03/leis/L3071.htm. Acesso em: 29 abril de 2020.

BRASIL. Código Civil de 2002. art. 1.275, III, e art. 1.276. Disponível em: http://www.planalto.gov.br/ccivil 03/leis/2002/l10406.htm. Acesso em: 29 abril de 2020.

BRASIL. Conselho Nacional de Direitos Humanos. Resolução $n^{0}$ 10, de 17 de outubro de 2018. Disponível em: https://www.gov.br/mdh/pt-br/assuntos/noticias/todas-as- 


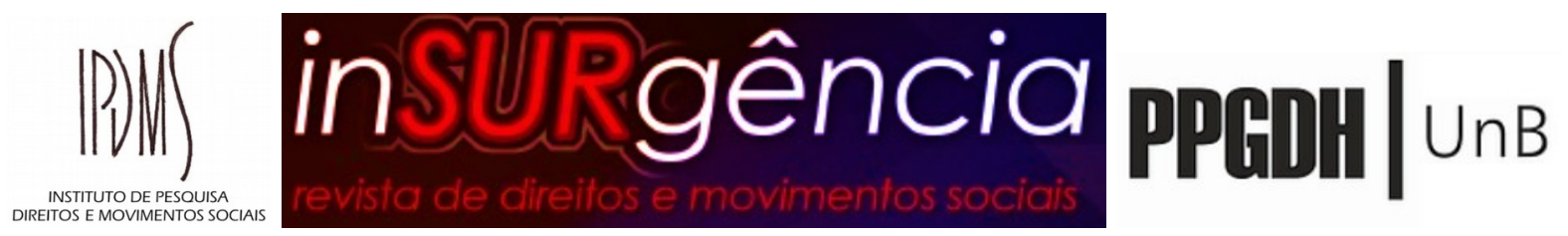

noticias/2018/outubro/resolucao-para-garantia-de-direitos-humanos-em-situacoes-deconflitos-por-terra-e-aprovada-pelo-conselho-nacional-dos-direitos-

humanos/copy of Resoluon10Resoluosobreconflitospossessriosruraiseurbanos.pdf/view. Acesso em: 29 de abril 2020.

BRASIL. Lei 13.465/17, art. 9; art. 10, art. 11; art. 13; art. 15; art. 23. art. 31, §8 ; art. 64; art. 65. Disponível em: http://www.planalto.gov.br/ccivil 03/ Ato20152018/2017/Lei/L13465.htm. Acesso em: 29 de abril de 2020.

BRASIL. Lei. 10.257 de 2017, Art. 2º XIV; art. 4', V, 'q'. Disponível em: http://www.planalto.gov.br/ccivil 03/leis/leis 2001/l10257.htm. Acesso em 29 de abril de 2020.

BRASIL. Pacto Internacional Sobre Direitos Econômicos, Sociais e Culturais. Disponível em: http://www.planalto.gov.br/ccivil 03/decreto/1990-1994/d0591.htm. Acesso em 29 de abril de 2020.

CAVALLAZZI, Rosângela Lunardelli. O estatuto epistemológico do direito urbanístico brasileiro: possibilidades e obstáculos na tutela do direito à cidade. In: COUTINHO, Ronaldo; BONIZZATO, Luigi (Coord.). Direito da cidade: novas concepções sobre as relações jurídicas no espaço social urbano. Rio de Janeiro: Lumen Juris, 2011, p. 47-62.

COSTA, Heloísa Soares de Moura. 2006. A cidade ilegal: notas sobre o senso comum e o significado atribuído à ilegalidade. In: BRANDÃO, Carlos Antônio Leite (org.). As cidades da cidade. Belo Horizonte: Editora da UFMG. p. 145-156.

COUTINHO, Ronaldo. A mitologia da cidade sustentável no capitalismo. In: COUTINHO, Ronaldo; BONIZZATO, Luigi (Coord.). Direito da cidade: novas concepções sobre as relações jurídicas no espaço social urbano. Rio de Janeiro: Lumen Juris, 2011, p. 17-46.

ENGELS, Friedrich. Sobre questão da moradia. São Paulo: Boitempo, 2015.

FERNANDES, Edésio; PEREIRA, Helena Dolabela. Legalização das favelas: qual é o problema de Belo Horizonte? Planejamento e políticas públicas, $n^{0}$ 34, p. 171-199, jan.-jun. 2010.

FERNANDES, Florestan. O que é revolução. In: PRADO JÚNIOR, Caio; FERNANDES, Florestan. Clássicos sobre a revolução brasileira. São Paulo: Expressão Popular, 2000, p. 55148.

GAIO, Daniel. O direito à cidade e seu processo de institucionalização no Brasil. In: GUSTIN, Miracy Barbosa de Sousa; LOPES, Mônica Sette; NICÁCIO, Camila Silva (Org.). Eficiência, eficácia e efetividade: velhos desafios ao novo código de processo civil. Belo Horizonte: Initia Via, 2016, p. 236-250.

GAIO, Daniel. O fetiche da lei e a reforma urbana no Brasil. In: COSTA, Geraldo Magela; COSTA, Heloisa Soares de Moura; MONTE-MÓR, Roberto Luís de (Org.). Teorias e práticas urbanas: condições para a sociedade urbana. Belo Horizonte: C/Arte, 2015, p. 283-296.

MIRANDA, Isabella Gonçalves; VASCONSELOS DE FREITAS. Luiz Fernando. Enquanto trabalhar for proibido, ocupar as ruas é um direito. Indisciplinar, Belo Horizonte, 2017. Disponível em: http://indebate.indisciplinar.com/2017/07/06/enquanto-trabalhar-for-proibidoocupar-as-ruas-e-um-direito/. Acesso em: 13 maio 2020.

IBGE. 2017. IBGE - cidades @. Disponível em: https://cidades.ibge.gov.br/brasil/mg/timoteo. Acesso em: 23 maio 2020. 


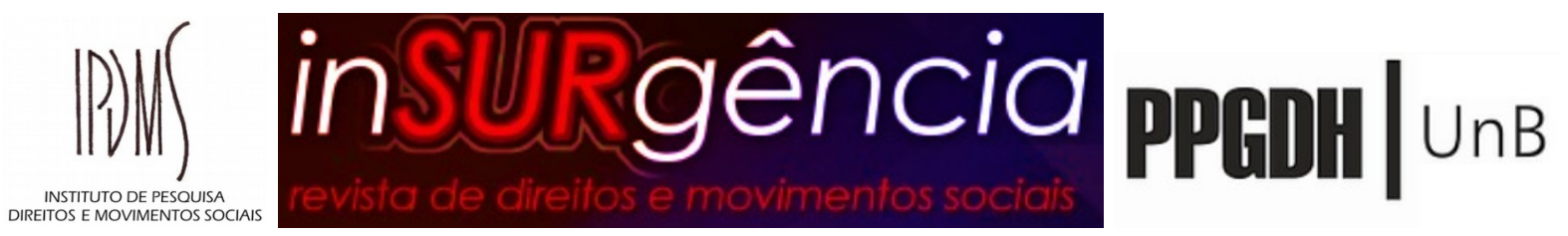

JESUS, Andreia de; MIRANDA, Isabella Gonçalves; VASCONCELOS DE FREITAS, Luiz Fernando; BITTENCOURT, Rafael Reis. Mesa Estadual de Diálogo e Negociação do Estado de Minas Gerais (MG): histórico de criação, funcionamento e perspectivas. Fundação Lauro Campos e Marielle Franco, São Paulo, 2019. Disponível em: https://www.laurocampos.org.br/2019/04/23/mesa-estadual-de-dialogo-e-negociacao-doestado-de-minas-gerais-mg-historico-de-criacao-funcionamento-e-perspectivas/. Acesso em: 20 maio 2020.

LEFEBVRE, Henri. O direito à cidade. São Paulo: Centauro Editora, 2011.

MINAS GERAIS. Assembleias Legislativa. Emenda parlamentar impositiva 501, descrita no inciso 479, da Lei 23.579/20, que estima as receitas e fixa as despesas do Orçamento Fiscal do Estado de Minas Gerais e do orçamento de Investimento das Empresas Controladas pelo Estado para o exercício financeiro de 2020.

MINAS GERAIS. Tribunal de Justiça de Minas Gerais. Apelação Cível 002303511.2012.8.13.0687. $8^{a}$ Câmara Cível. Relator: Desembargador Alexandre Santiago. Disponível em: $\quad$ https://www4.tjmg.jus.br/juridico/sf/proc complemento2.jsp? listaProcessos=10687120023035010. Acesso em 21 de abril de 2020.

MINAS GERAIS. Tribunal de Justiça de Minas Gerais. Apelação Cível, Reexame Necessário 0031921-96.2012.8.13.0687. 8ª Câmara Cível. Relator: Desembargador Alexandre Santiago. Disponível em: $\quad$ https://www4.tjmg.jus.br/juridico/sf/proc complemento2.jsp? listaProcessos=10687120031921014. Acesso em 21 de abril de 2020.

MINAS GERAIS. Tribunal de Justiça de Minas Gerais. Apelação Cível 004630904.2012.8.13.0687. 18 ${ }^{\mathrm{a}}$ Câmara Cível. Relator: Desembargador Arnaldo Maciel. Disponível em: https://www4.tjmg.jus.br/juridico/sf/proc complemento2.jsp? listaProcessos=10687120046309002. Acesso em 21 de abril de 2020.

MINAS GERAIS. Tribunal de Justiça de Minas Gerais. Ação de Reintegração de Posse 0512523-53.2015.8.13.0024 e 0512531-30.2015.8.13.0024. Vara Agrária. Disponível em: https://www4.tjmg.jus.br/juridico/sf/proc complemento.jsp? comrCodigo=24\&numero=1\&listaProcessos=15051252. Acesso em 21 de abril de 2020.

MINAS GERAIS. Tribunal de Justiça de Minas Gerais. Ação Cautelar 081913421.2015.8.13.0000. $8^{\mathrm{a}}$ Câmara Cível. Relator: Desembargador Alexandre Santiago. Disponível em: $\quad$ https://www4.tjmg.jus.br/juridico/sf/proc complemento.jsp? comrCodigo=24\&numero=1\&listaProcessos=15051252. Acesso em 21 de abril de 2020.

MINAS GERAIS. Tribunal de Justiça de Minas Gerais. Agravo de Instrumento 1.0000.17.061726/0-002. 10ª Câmara Cível. Relator: Desembargador Maurício Pinto Ferreira. Disponível em: https://www4.tjmg.jus.br/juridico/sf/proc complemento2.jsp? listaProcessos=10000170617260002. Acesso em 21 de abril de 2020.

MINAS GERAIS. Tribunal de Justiça de Minas Gerais. Agravo de Instrumento 1.0024.02.683314-5 (001). 2 2 Câmara Cível. Relator: Desembargador Marcelo Rodrigues. Disponível em:_https://pe.tjmg.jus.br/rupe/assinarConteudo? $\underline{\text { acao }=\text { download \& viewFile }=\text { true\&desenveloparArquivoAssinado=true\&adicionarLinkValidaca }}$

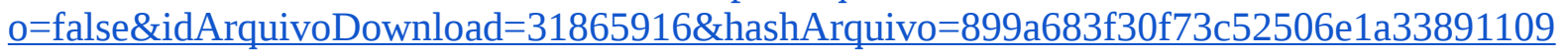
e3. Acesso em: 10 maio 2020.

MINAS GERAIS. Tribunal de Justiça de Minas Gerais. Agravo de Instrumento 1.0024.15.051252-3/006. 10 $10^{\text {a }}$ Câmara Cível. Relator: Desembargador Cabral da Silva. 


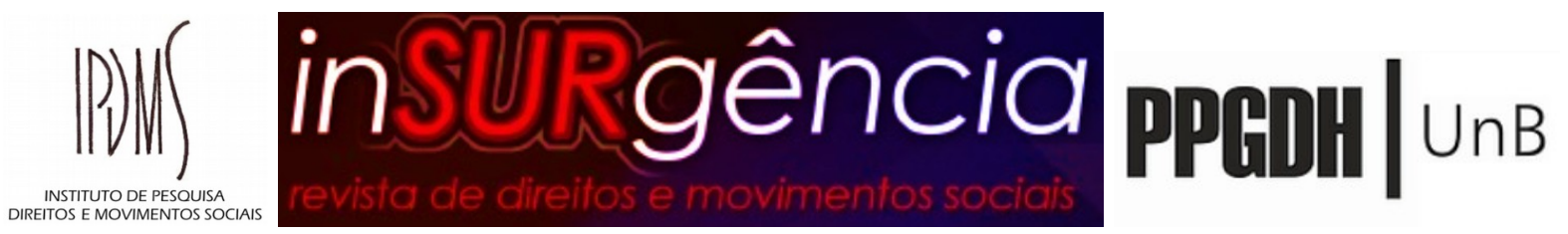

Disponível em: https://www4.tjmg.jus.br/juridico/sf/proc complemento2.jsp? listaProcessos=10024150512523006. Acesso em: 21 de abril de 2020.

MULLER, Cristiano. Os conflitos fundiários urbanos no Brasil desde uma perspectiva crítica dos direitos humanos. In: FERNANDES, Edésio; ALFONSIN, Betânia (Coord.). Direito à moradia adequada: o que é, pra que serve e como defender e efetivar. Belo Horizonte: Fórum, 2014, p. 161-182.

NASCIMENTO, Denise Morado. Outra lógica da prática. In: NASCIMENTO, Denise Morado (Org.). Saberes [auto]construídos. Belo Horizonte: Associação Imagem Comunitária, 2016.

ONU. Comentários Gerais no 4 e 7 do Comitê de Direitos Econômicos, Sociais e Culturais. Disponível em: http://pfdc.pgr.mpf.mp.br/atuacao-e-conteudos-de-apoio/legislacao/reformaagraria/ComentarioGeral7 DESC/view. Acesso em 29 de abril de 2020.

RIBEIRÃO DAS NEVES. Câmara Municipal. Moção 043/2019.

RIBEIRÃO DAS NEVES. Prefeitura Municipal. Portaria/Gab n. ${ }^{\circ}$ 056/2018.

ROLNIK, Raquel. Guerra dos lugares: a colonização da terra e da moradia na era das finanças. São Paulo: Boitempo, 2015.

SILVA, Ana Amélia da. Reforma urbana e o direito à cidade. São Paulo: Revista Pólis, $\mathrm{n}^{\circ}$. 01, p. 1-42, 1991.

SOUZA, Marcelo Lopes de. Ação direta e luta institucional: complementaridade ou antítese? ( $1^{\text {a }}$ e $2{ }^{\text {a }}$ partes). Passa Palavra, Florianópolis, abr. 2012.

TAVOLARI, Bianca. Direito à cidade: uma trajetória conceitual. Novos Estudos Cebrap, $\mathrm{n}^{0}$ 104, p. 93-109, mar. 2016.

TORRES, Marcos Alcino de Azevedo. A propriedade e a posse: um confronto em torno da função social. Rio de Janeiro: Lumen Juris, 2010.

VASCONCELOS DE FREITAS, Luiz Fernando. Entrevista de Vicente Gonçalves. Do Provafela à Izidora: a luta pelo direito à cidade em Belo Horizonte. Dissertação de Mestrado. Programa de Pós-Graduação em Direito da Universidade Federal de Minas Gerais, 2015.

Submetido em 31/05/2020.

Aprovado em 21/07/2020. 